International Journal of Oceanography and Hydrobiology Volume 50, No. 4, December 2021

\title{
Determination of functional structure of soft-bottom marine macrobenthic communities of the Samsun Shelf Area using biological traits analysis
}

by

\section{Ayşe Van*, Aysun Gümüş̧}

\section{DOI: 10.2478/oandhs-2021-0040 \\ Category: Original research paper \\ Received: April 19, 2021 \\ Accepted: July 1, 2021}

Ondokuz Mayıs University, Faculty of Science and Arts, Department of Biology, Samsun, Turkey

\begin{abstract}
Biological Traits Analysis (BTA) was used to investigate the functional structure of marine macrobenthic communities along the Samsun Shelf Area (SSA). Benthic samples were collected seasonally from five different locations and at four different depths using a Van Veen grab sampler. Macrofaunal communities distributed in the SSA were assessed using 10 biological traits to identify characteristic traits for each depth and location. It was found that variability of benthic ecosystem functions in the SSA was driven by biological traits such as maximum size, living habit, sediment position, feeding mode and type of reproductive behavior. Bivalves, polychaetes and crustaceans of small to medium size, biodepositing, burying themselves in the sediment (burrowers) and feeding in suspension were relatively more abundant at depths of 0-60 m. However, the biomass of Amphiura, Abra, Papillicardium and some polychaetes characterized by medium to large sizes, diffusive mixing, free living and feeding on deposit and subsurface deposit showed higher values at depths below $60 \mathrm{~m}$. In general, it is concluded that the functional structure of the benthic infauna in the SSA has adapted to physical disturbance, and communities distributed in this area consist mainly of taxa resistant to mechanical pressure.
\end{abstract}

Key words: biological traits, benthic communities, fishing pressure, Black Sea

*Corresponding author:van_55.1986@hotmail.com 


\section{Introduction}

Marine sediment communities have been the subject of numerous ecological studies regarding their adaptability to environmental changes and, more importantly, their role in the seabed functioning and ecosystem services. Benthic invertebrate communities are the most studied components of the marine ecosystem using BTA. These communities consist of a wide variety of species that exhibit a high diversity of life types characteristic of the complex spatial and temporal structure of seabed habitats. Most of these species have limited mobility and relatively shorter lifespans compared to other animal groups, such as fish. For this reason, these communities become indicators of environmental changes. This probably explains why benthic invertebrate characteristics, benthic habitats, and human impact are more frequently documented in search results (Beauchard et al. 2017). In marine ecosystems, macrobenthos plays an important role in ecosystem processes such as nutrient cycling, sediment oxygenation, organic matter decomposition (Bremner 2005), secondary production (Bolam \& Eggleton 2014), metabolic waste transformation and separation of toxic substances (Gilbert et al. 1994).

Biological traits of benthic organisms are used as a key to better understand ecosystem processes and functions. Biological traits are life history characteristics of species and are often used to understand the structure and dynamics of ecological communities (Dray et al. 2014). The functional importance of these processes is strongly related to the form of invertebrate activity (Beaumont \& Tinch 2003; Solan et al. 2008). Properties that were effective in processes involving benthic species can be used as an indicator of ecosystem functioning. Bolam (2012), Bolam et al. (2014), Bremner (2008), Paganelli et al. (2012), van der Linden et al. (2012), van Son et al. (2013) argued that assessments based on a set of traits provide a better understanding of ecosystem functions than assessments based on benthic community structure. Direct measurements of ecological functions are both time consuming and burdened with methodological and logistic difficulties. A large number of recently developed functional diversity indices allow the measurement of functional diversity (Wan Hussin et al. 2012). BTA, in particular, which has been used recently, provides a better understanding of benthic functional responses to multiple forms of human impact (Bremner et al. 2003; Tillin et al. 2006; Frid 2011; Wan Hussin et al. 2012; Oug et al. 2012; Munari 2013; Bolam et al. 2014; Muntadas et al. 2015; Donadi et al. 2015). The use of
BTA as a method for describing ecological functioning (Doledec \& Statzner 1994) of marine benthic assemblages has become widespread in recent years (Bremner 2008; Paganelli et al. 2012; van der Linden et al. 2012; Bolam et al. 2014; Nasi et al. 2018; Kun et al. 2019). BTA uses various life history, behavioral and morphological traits of species present in a community to represent all aspects of the ecological functioning of species. The biological trait approach uses information about variation in the composition of trait categories to represent some aspects of the species functioning. Species with different biological traits respond differently to fisheries and similar effects. Different assemblages display different functional responses (Tillin et al. 2006).

The Samsun Shelf Area is a marine habitat that has been subject to severe physical disturbance for many years, particularly caused by bottom towed gear (bottom and beam trawls). The purpose of this paper is primarily to describe the current functional structure of the SSA ecosystem. We attempted to determine functional responses of marine benthic macrofaunal invertebrate populations to anthropogenic changes using biological traits analysis. Fishing pressure and other factors may have changed and restructured marine species, taxa groups and assemblages in the area. This process of change is likely to affect the functioning of the entire ecosystem. The study will contribute to the understanding of how macrobenthic assemblages participate in ecosystem functioning in an area under high fishing pressure, such as the SSA in the south-central Black Sea.

\section{Material and methods}

\subsection{Study area and Sampling}

Sampling was performed seasonally in December 2013, April 2014, July 2014 and October 2014. A total of 80 biological samples were collected at 20 stations in five different localities - Terme ( $T$ ), Fenerkoy (F), Canik (C), Derekoy (D) and Kosukoyu (K), and at four different depths: $0-20 \mathrm{~m}$ (1), 20-40 m (2), 40-60 m (3) and > $60 \mathrm{~m}$ (4) along the SSA (Fig. 1). The substations were coded by station initials and a depth range number (e.g. F1 = Fenerkoy at 0-20 m; C3 = Canik at 40-60 m). Sediment samples were collected as two replicates using a Van Veen grab sampler $\left(0.1 \mathrm{~m}^{2}\right)$. All samples were sieved through $0.5 \mathrm{~mm}$ mesh and stored in $70 \%$ ethanol. Biological specimens were examined under a stereomicroscope and identified to the lowest possible taxonomic level. 


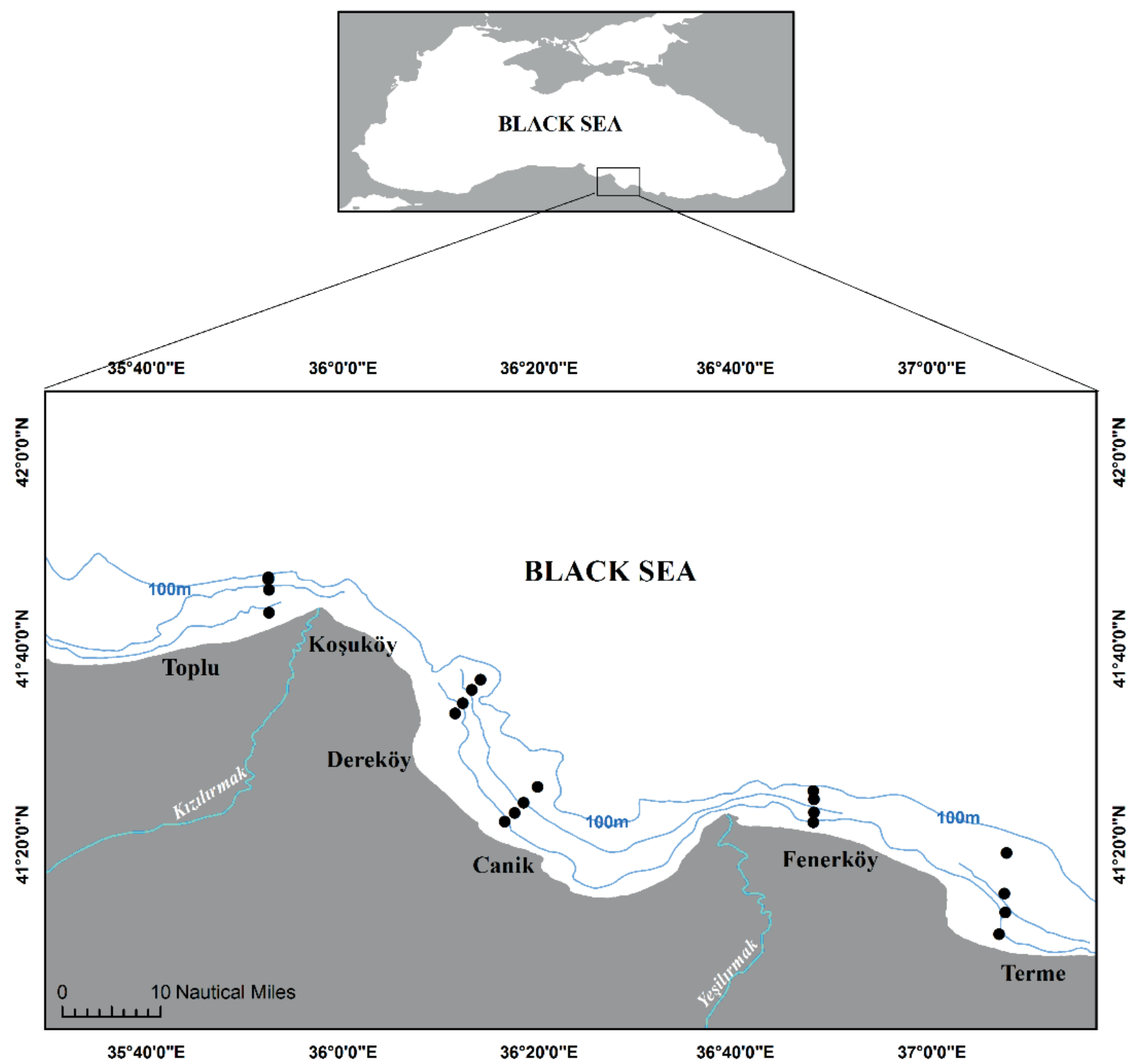

Figure 1

Benthic sampling stations and substations in the Samsun Shelf Area

The number of taxa and wet weight were recorded on forms. Biomass $\left(\mathrm{g} \mathrm{m}^{-2}\right)$ and abundance $\left(\mathrm{N} \mathrm{m}^{-2}\right)$ were calculated for each taxon at each sampling station. Macrobenthic community abundance and biomass data were normalized using log $(x+1)$ transformation to minimize the effect of dominant taxa in samples (Clarke \& Warwick 1994).

\subsection{Biological Traits Analysis (BTA)}

In this study, 10 biological traits were selected to describe functional characteristics of marine macrobenthic taxa. Each trait was divided into categories to include all character types of traits exhibited by taxa. The selected traits were described by a total of 48 categories (Table 1). For example, the trait "larval development strategy" was divided into the "pelagic-planktotrophic", "pelagic-lecithotrophic", and "benthic-direct" categories.

Most taxa exhibit multiple behaviors depending on specific conditions and availability of resources, so assigning them to a single category may be incorrect (Usseglio-Polatera et al. 2000). Therefore, an individual taxon exhibiting various categories of each trait was scored using the "fuzzy coding" procedure as described by Chevenet et al. (1994). Depending on a 
Table 1

\begin{tabular}{|c|c|c|c|}
\hline \multicolumn{4}{|c|}{ List of traits and categories used in BTA } \\
\hline Traits & No. & Category & $\begin{array}{l}\text { Trait } \\
\text { code }\end{array}$ \\
\hline \multirow{6}{*}{$\begin{array}{l}\text { Maximum size } \\
(\mathrm{mm})\end{array}$} & 1 & $<10$ & S1 \\
\hline & 2 & $11-20$ & S2 \\
\hline & 3 & 21-100 & S3 \\
\hline & 4 & $101-200$ & S4 \\
\hline & 5 & $201-500$ & S5 \\
\hline & 6 & $>500$ & S6 \\
\hline \multirow{5}{*}{ Bioturbation } & 1 & Diffusive mixer & B1 \\
\hline & 2 & Surface deposition & B2 \\
\hline & 3 & Upward conveyor & B3 \\
\hline & 4 & Downward conveyor & B4 \\
\hline & 5 & None & B5 \\
\hline \multirow{6}{*}{ Morphology } & 1 & Soft & M1 \\
\hline & 2 & Tunic & M2 \\
\hline & 3 & Exoskeleton & M3 \\
\hline & 4 & Crustose & M4 \\
\hline & 5 & Cushion & M5 \\
\hline & 6 & Stalked & M6 \\
\hline \multirow{4}{*}{ Longevity (year) } & 1 & $<1$ & L1 \\
\hline & 2 & $1-2$ & L2 \\
\hline & 3 & $3-10$ & L3 \\
\hline & 4 & $>10$ & L4 \\
\hline \multirow{3}{*}{$\begin{array}{l}\text { Larval development } \\
\text { strategy }\end{array}$} & 1 & Pelagic/planktotrophic & LD1 \\
\hline & 2 & Pelagic/lecithotrophic & LD2 \\
\hline & 3 & Benthic (direct) & LD3 \\
\hline \multirow{4}{*}{ Reproduction type } & 1 & Asexual & RT1 \\
\hline & 2 & Sexual/eggs (pelagic) & RT2 \\
\hline & 3 & Sexual/eggs (benthic) & RT3 \\
\hline & 4 & Sexual/brood eggs & RT4 \\
\hline \multirow{6}{*}{ Living habit } & 1 & Tube-dwelling & LH1 \\
\hline & 2 & Burrow-dwelling & LH2 \\
\hline & 3 & Free living & LH3 \\
\hline & 4 & Crevice/under stone & LH4 \\
\hline & 5 & Epi/endo zoic/phytic & LH5 \\
\hline & 6 & Attached to seabed & LH6 \\
\hline \multirow{4}{*}{ Sediment position } & 1 & Surface & SP1 \\
\hline & 2 & Shallow infauna $(0-5 \mathrm{~cm})$ & SP2 \\
\hline & 3 & Mid-depth infauna $(5-10 \mathrm{~cm})$ & SP3 \\
\hline & 4 & Deep infauna (> $10 \mathrm{~cm})$ & SP4 \\
\hline \multirow{6}{*}{ Feeding mode } & 1 & Suspension & FM1 \\
\hline & 2 & Surface deposit & FM2 \\
\hline & 3 & Subsurface deposit & FM3 \\
\hline & 4 & Scavenger/opportunist & FM4 \\
\hline & 5 & Predator & FM5 \\
\hline & 6 & Parasite & FM6 \\
\hline \multirow{4}{*}{ Mobility } & 1 & Sessile & Mob1 \\
\hline & 2 & Swim & Mob2 \\
\hline & 3 & Crawl/creep/climb & Mob3 \\
\hline & 4 & Burrower & Mob4 \\
\hline
\end{tabular}

taxon' affinity to a given trait category, each trait was assigned a score ranging from 0 to 3 , where 0 indicates no affinity to a trait category, 1 or 2 indicate partial affinity and 3 indicates high affinity. For instance, Upogebia pusilla was coded as suspension $=3$, surface deposit $=3$, subsurface deposit $=3$, scavenger/ opportunist $=0$, predator $=0$ and parasite $=0$ for the trait category of "feeding mode".

Information on marine benthic invertebrates in this aspect is rather scattered. Therefore, we collected data on all traits mainly from published papers, expert opinions, and the BIOTIC database (the Biological Traits Information Catalogue developed by the Marine Life Information Network http://www.marlin.ac.uk/ biotic). While information on specific traits such as larval development strategy and morphology was available for most taxa, adequate information was not available for other traits such as life span. In such a case, a zero value was assigned to all categories for a trait in a number of studies (Usseglio-Polatera et al. 2000; Tillin et al. 2006; Bremner et al. 2006; Paganelli et al. 2012). Instead, we adopted the approach of using information on the most related taxa entries to assign a category score (Bolam \& Eggleton 2014). Three matrices had to be prepared before moving to the next steps of the BTA. A "traits by stations matrix" was created by combining two matrices. The first is the "taxa abundance/biomass by stations matrix" and the second is the "taxa by trait matrix". The "taxa by trait matrix" contains biological trait scores (fuzzy-coded data) for each taxon and the "traits by stations matrix" contains frequencies of biological traits at each station.

The $x 2$ (chi-square) test was performed using the "biomass-based average frequency table" for each station to detect any significant relationships between the stations and categories. "Traits by stations" matrices were prepared by using both abundance and biomass data. "Traits by stations" matrices based on abundance and biomass were then compared with the RELATE routine in PRIMER.

The "traits by stations matrix" was analyzed using Fuzzy Correspondence Analysis (FCA) (Chevenet et al. 1994) to describe the distribution of biological traits within assemblages and to identify the traits responsible for differences. The software ade4TkGUI package in R-3.0.2 (www.R-project.org/) was used to perform FCA.

There are published studies that have tested how abundance- or biomass-based data affect the relationship between trait composition and functions (Villnäs et al. 2012; Bolam \& Eggleton 2014; Darr et al. 2014; Gogina et al. 2014). Although it is generally accepted that biomass-based data are stronger and more suitable for explaining ecosystem functioning 
(Bremner et al. 2006; Cesar \& Frid 2009; Darr et al. 2014), abundance-based and biomass-based data were checked for a significant correlation in this study prior to biological trait analysis.

\section{Results}

A total of 53 different taxa were identified in the study area: Mollusca (20), Annelida (14), Arthropoda (13), Nemertea (2), Echinodermata (1), Cnidaria (1), Phoronida (1) and Chordata (1). Bivalves, polychaetes, gastropods, and echinoderms are the most abundant in the area. Bivalves contribute the highest abundance and biomass at almost all stations. They reached the highest abundance in Canik $\left(3367 \mathrm{~N} \mathrm{~m}^{-2}\right.$ ) and the highest biomass $\left(5379.95 \mathrm{~g} \mathrm{~m}^{-2}\right)$ in Kosukoyu. Chamelea sp. is the most common taxa at a depth of $0-20 \mathrm{~m}$ at all stations. The other most common taxa at all stations were bivalves Pitar sp. and Abra sp. Only the Terme substations were characterized by the highest abundance of polychaetes with a total of 630 individuals, followed by 595 and 468 individuals of bivalves and echinoderms, respectively. The Canik station was characterized by the highest abundance with $4195 \mathrm{~N} \mathrm{~m}^{-2}$ and the Kosukoyu station had the highest biomass with $5420.85 \mathrm{~g} \mathrm{~m}^{-2}$.

Biological trait scores for each macrobenthic taxon, prepared according to the 'fuzzy coding' approach, are presented in the supplementary material. The $x 2$ test performed for all traits shows a significant correlation $(p<0.001)$ between the trait categories and the sampling stations. It was observed that for each trait at least one station was different from the others in its biological profile. For example, organisms with a size range of 101-200 mm and a lifespan of 3-10 years dominated only at Terme, while a size range of
21-100 mm and a lifespan of $>10$ years dominated at all other stations. It was observed that there was a strong correlation between the abundance-based trait matrix and the biomass-based trait matrix tested using the RELATE routine in PRIMER $(\rho=0.933, p<0.001)$. Due to this strong correlation between abundance and biomass, only biomass data were used in all functional analyses. Biomass-based FCAs were performed to analyze functional structures of macrobenthic communities in the Black Sea.

\subsection{Winter period}

The first two axes of FCA accounted for $61 \%$ of the total variance in the composition of biological traits at the sampling stations during winter. The FCA indicated that axis 1 and axis 2 contributed $35 \%$ and $26 \%$ of the variation, respectively. The correlation ratios (RS) of each trait contributing to the total variance are presented in Table 2 . The RS corresponds to the proportion of the total variance by each axis. The maximum size, longevity, and larval development strategy are distributed along axis 1. Biological traits along axis 2 were dominated by position in the sediment and mobility (Table 2 ). The reproductive type is well correlated with both axes, while bioturbation and morphology are not.

Station F2 is more distinct from other stations and is located along axis 1. Organisms having the traits of '< $10 \mathrm{~mm}^{\prime}$ in maximum size, '< 1 year' in longevity and asexual reproduction have high biomass at F2. Biomass of benthic and seabed-attached or epi/endo/zoic/ phytic organisms was high. Station T1 along axis 2 was characterized by trait modality: mid-depth infauna sediment position, subsurface deposit-feeding mode, crawling/creeping/climbing or burrowing mobility, sexual/brood eggs (Fig. 2).

Table 2

Correlation ratios of traits on the first two FCA axes for all seasons

\begin{tabular}{|l|c|c|c|c|c|c|c|c|}
\hline & \multicolumn{2}{c|}{ winter } & \multicolumn{2}{c|}{ spring } & \multicolumn{2}{c|}{ summer } & \multicolumn{2}{c|}{ autumn } \\
\hline \multicolumn{1}{|c|}{ Correlation ratios } & RS1 & RS2 & RS1 & RS2 & RS1 & RS2 & RS1 & RS2 \\
\hline \multicolumn{1}{|c|}{ Relative inertia (\%) } & 35 & 26 & 29 & 20 & 30 & 21 & 32 & 26 \\
\hline Maximum size & 0.5490 & 0.1615 & 0.3597 & 0.1283 & 0.2874 & 0.0571 & 0.3890 & 0.5323 \\
\hline Bioturbation & 0.0090 & 0.0271 & 0.0142 & 0.1117 & 0.1321 & 0.1815 & 0.0620 & 0.0312 \\
\hline Morphology & 0.0092 & 0.0504 & 0.0068 & 0.0337 & 0.0446 & 0.2254 & 0.0032 & 0.0043 \\
\hline Longevity & 0.4668 & 0.1531 & 0.2345 & 0.1897 & 0.0758 & 0.0542 & 0.2916 & 0.2357 \\
\hline Larval development strategy & 0.3142 & 0.0633 & 0.1913 & 0.0591 & 0.0122 & 0.1098 & 0.2944 & 0.1232 \\
\hline Reproduction type & 0.4610 & 0.4037 & 0.3905 & 0.4111 & 0.2464 & 0.0562 & 0.4806 & 0.2636 \\
\hline Living habit & 0.2198 & 0.1312 & 0.1099 & 0.1487 & 0.1082 & 0.1958 & 0.1424 & 0.0241 \\
\hline Sediment position & 0.1260 & 0.3558 & 0.3886 & 0.2892 & 0.2397 & 0.1433 & 0.3168 & 0.6197 \\
\hline Feeding mode & 0.1712 & 0.2387 & 0.1783 & 0.0386 & 0.1842 & 0.0415 & 0.1741 & 0.0847 \\
\hline Mobility & 0.0412 & 0.1900 & 0.2343 & 0.0438 & 0.2013 & 0.0071 & 0.8181 & 0.4361 \\
\hline
\end{tabular}



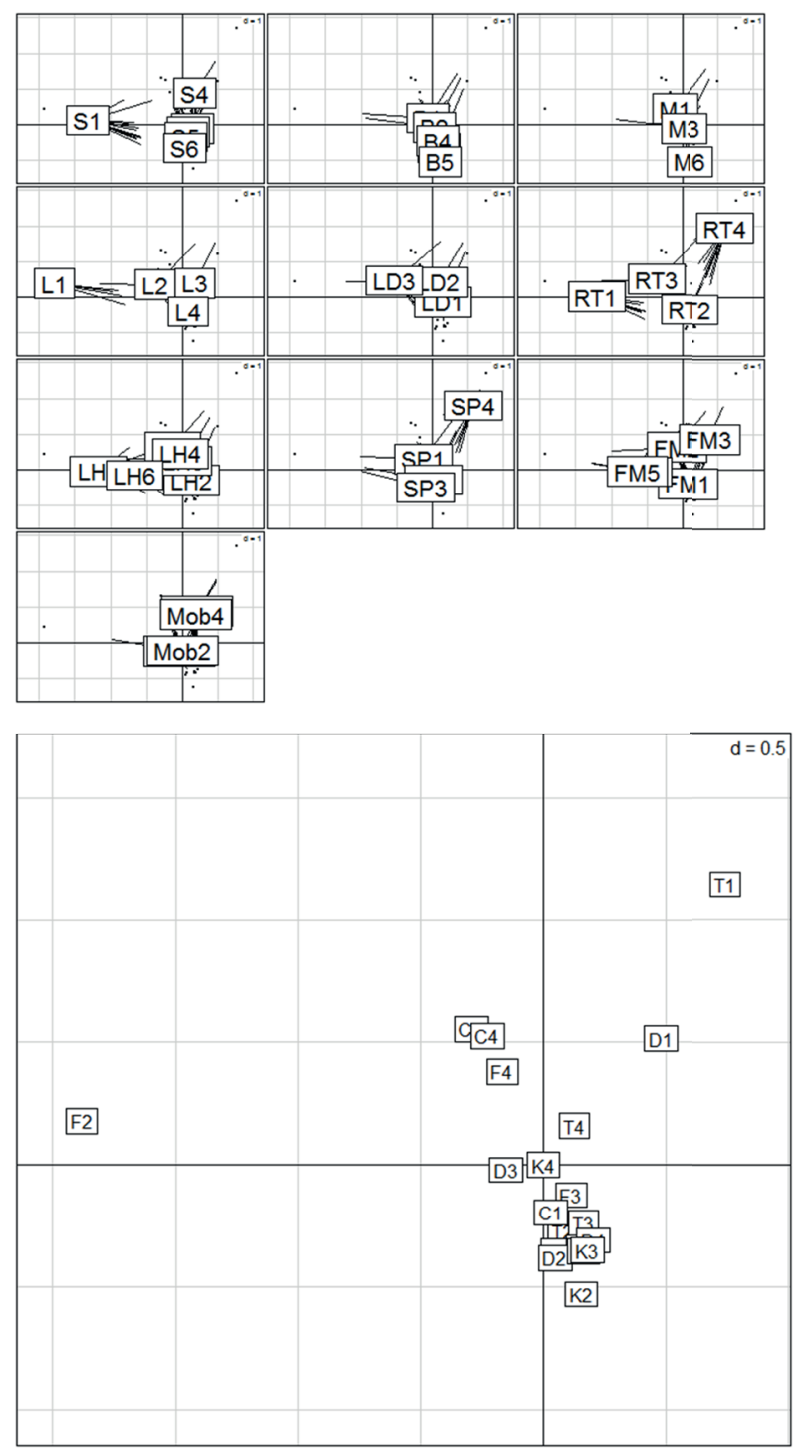

Figure 2

Factor map showing the ordination of 48 modalities of 10 biological traits and factor map of sampling stations obtained by FCA for winter ( $\mathrm{d}=1$ or $\mathrm{d}=0.5$ is a distance scale indicating the length of sides of gray squares)

\subsection{Spring period}

FCA explained $49 \%$ of the total variance in spring, with axis 1 accounting for $29 \%$ and axis 2 accounting for $20 \%$ of the variance. Biological traits located along FCA axis 1 were larval development strategy, feeding mode and mobility, whereas bioturbation was located along axis 2. Morphology showed weak correlation with both axes. The maximum size, sediment position, and reproduction type were strongly correlated with both axis 1 and axis 2. These biological traits separated communities located in different areas and depths. Substations T1, D1, C1, and K4 are quite different in terms of traits and are located separately from other stations (Fig. 3), which were close to each other in the FCA factorial plane and thus show a similar composition in trait categories.

Macrobenthos assemblages at substation C1 were dominated by species that are upward or downward conveyors and swimmers. Substation K4 was distinguished by small $(<10 \mathrm{~mm})$, short life span $(<1$ year), epi/endo/zoic/phytic or attached to the seabed, and asexual modalities. Macrobenthos occurring at substations $\mathrm{T} 1$ and $\mathrm{D} 1$ is characterized by deep
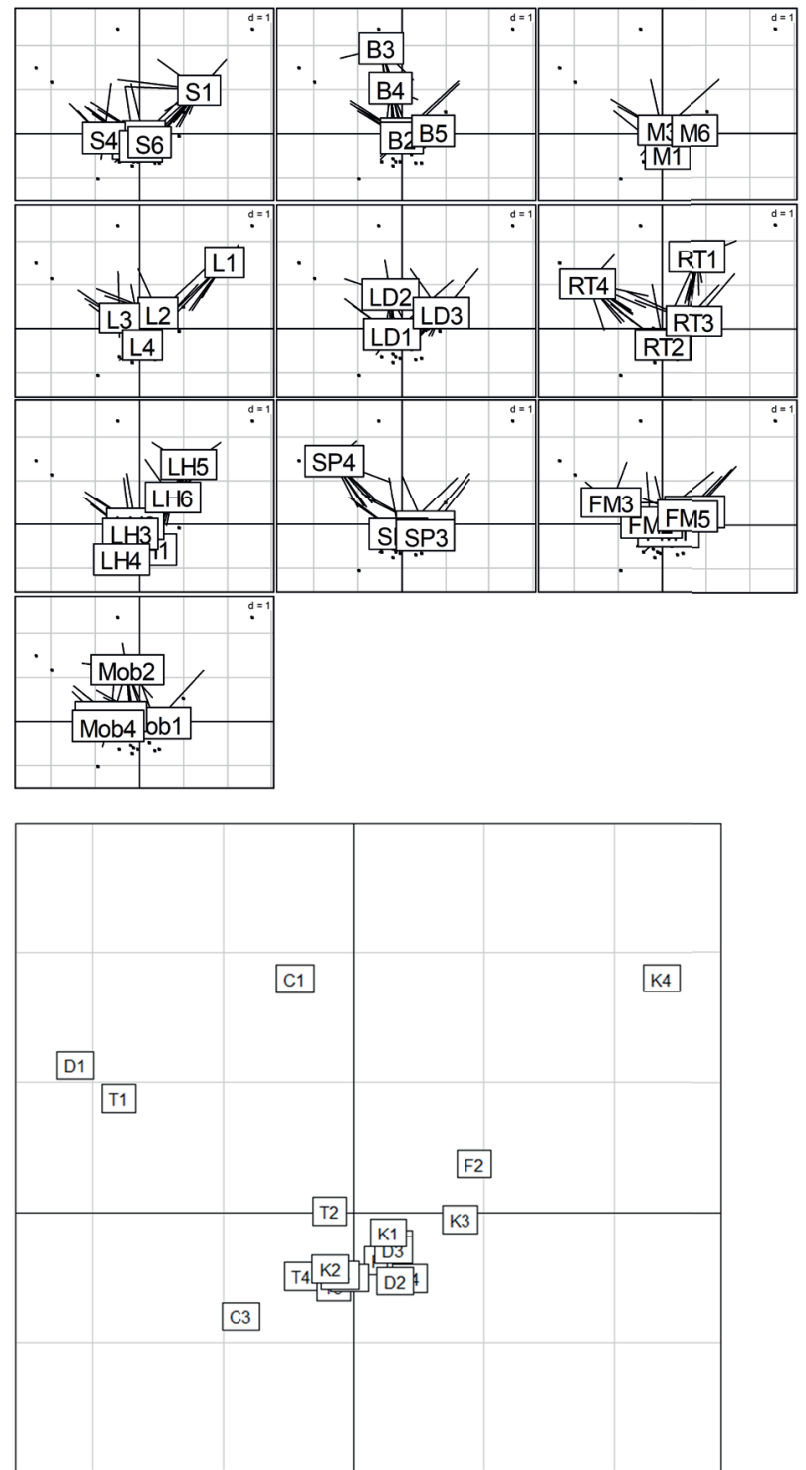

Figure 3

Factor map showing the ordination of 48 modalities of 10 biological traits and factor map of the sampling stations obtained by FCA for spring 
infauna $(>10 \mathrm{~cm})$, subsurface deposit and benthic larval development modalities. Modalities such as planktotrophic larval development, sexual/eggs (pelagic or benthic) reproduction type, and surface or shallow infauna $(0-5 \mathrm{~cm})$ sediment location may be accepted as a functional profile that represents the general character of the spring season. Through these biological traits, different groups of organisms appear to perform similar functions.

\subsection{Summer and autumn period}

More than $50 \%$ of the total variance during summer was explained by the first two FCA axes. Axis 1 accounts for $30 \%$ of the total variance in the composition of traits such as maximum size, reproduction type, feeding mode, and mobility. The modalities of morphology and larval development strategy are distributed along axis 2 and explain $21 \%$ of the total variance. Longevity is weakly correlated with both axes, whereas living habit, sediment position, and bioturbation are strongly correlated (Table 2).

The FCA factor map shows that the stations spread along axis 2. Terme, Canik and Dereköy substations differed from each other. Fenerköy and Kosukoyu substations showed similar distributions of traits. The FCA plane showed that the depth ranges $(0-40 \mathrm{~m}$ and $40-80 \mathrm{~m}$ ) may be the main factor in the functional distribution in the area (Fig. 4).

The deep Dereköy, Canik and Fenerköy sampling stations appear to have similar biological trait characteristics. On the other hand, all of the Terme substations and the 0-20 m Dereköy substation were different in terms of trait profiles and were located along axis 1 . Stations distributed along axis 2 included "stalked" and "tunic" modalities within the trait morphology, bioturbation "upward and downward conveyor" and "none", lecithotrophic larvae, living habit epi/endo/zoic/phytic or attached to seabed species (Fig. 4). The biomass was high for "101-200 $\mathrm{mm}$, upward conveyor, swimming, crawling, creeping, climbing, subsurface deposit, sexual/brood eggs, mid-depth infauna $(5-10 \mathrm{~cm})$ " organisms at $\mathrm{T} 1, \mathrm{~T} 4$, and D4 stations (distributed along axis 2), which were more distinct from other stations.

For the autumn period, $50 \%$ of the total variance is explained by the first two axes (Table 2). Mobility, maximum size, reproduction type, and sediment position were the trait modalities that contributed most to the variation. The correlation of "bioturbation, morphology, feeding mode, and living habit" traits with the first two axes was weak. Mobility is a biological trait that shows a strong correlation with both axes.
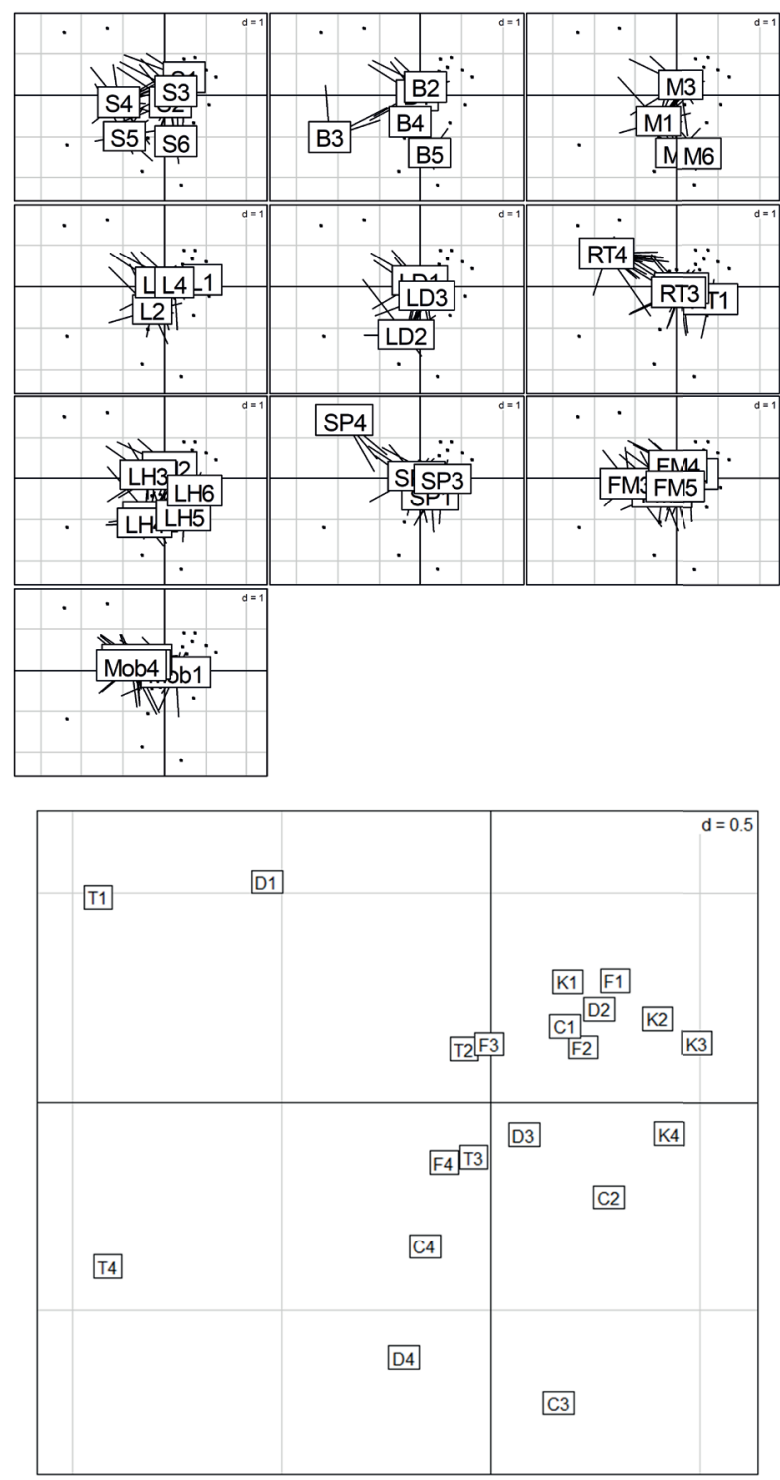

Figure 4

Factor map showing the ordination of 48 modalities of 10 biological traits and factor map of the sampling stations obtained by FCA for summer

It is clear that differences in the trait composition discriminate stations by producing biomass of different sizes belonging to different taxa. The FCA factor map shows that the stations were grouped according to the depth range. Two groups of stations showing different trait profiles are distinguished by depth: $0-20,20-40$, and $40-60 \mathrm{~m}$ as the first one and > $60 \mathrm{~m}$ as the second one (Fig. 5).

T1, T2, and D3 were different from other stations. Substation D3 was located on the negative side of axis 1, while $\mathrm{T} 1$ and $\mathrm{T} 2$ had negative axis 2 values. T1 and $\mathrm{T} 2$ were characterized by $101-200 \mathrm{~mm}$ size, 3-10 

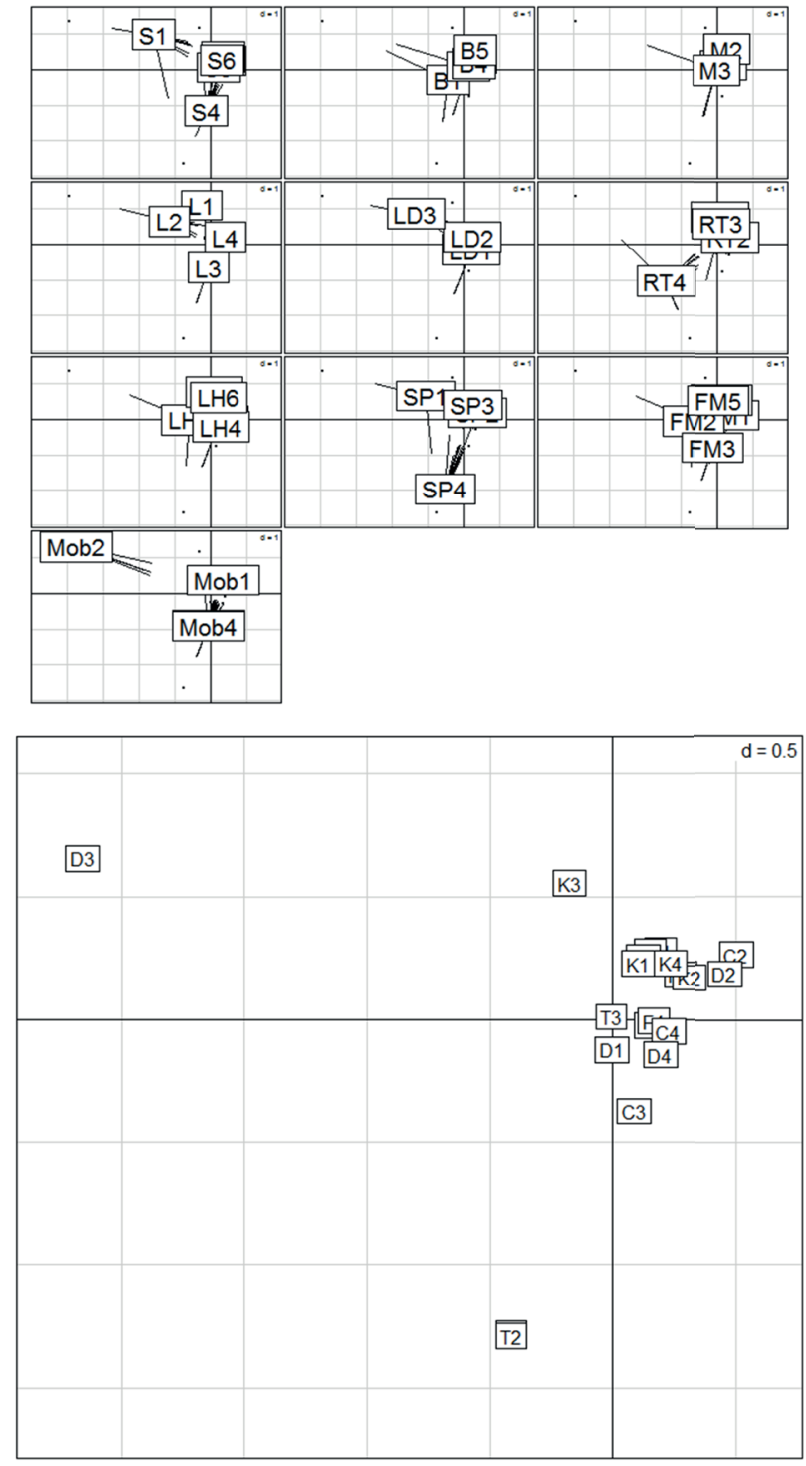

Figure 5

Factor map showing the ordination of 48 modalities of 10 biological traits and factor map of the sampling stations obtained by FCA for autumn

years life span, mid-depth infauna position, crawl/ creep/climb and burrow modalities. The structure of biological traits was slightly different at substation D3. The trait modalities were dominated by benthic larval development, sexual/brood eggs reproduction, and high mobility (swimmer) at D3. Therefore, two distinct groups can be defined for the traits of sediment position and mobility traits. The first one is the functional type with surface to $0-5 \mathrm{~m}$ infauna position and swimmer-sessile categories, and the second one is the functional type with 5-10 m infauna position-burrow categories (Fig. 5).

\section{Discussion}

The objective of this study was to investigate the functional structure of the SSA using biological trait analysis and fuzzy coding, and to determine the ecosystem functioning based on 'trait-function' relationships. The research was carried out to evaluate the current functional structure of microbenthic assemblages under fishing pressure and to determine the contributing trait composition in this affected area. The FCA allowed us to assess the functional composition in the SSA. Two groups appeared on the FCA factor maps in autumn and winter. Although the distinction between the groups is not very sharp, the macrobenthic community at a depth of $60 \mathrm{~m}$ was mainly dominated by organisms characterized by modalities of 101-200 mm size, crawler/creeper/ climber, surface/subsurface deposit feeder, surface/ infauna positioning, benthic/pelagic lecithotrophic larvae and sexual/eggs, (benthic)/sexual/brooded eggs. The community at depths of $0-60 \mathrm{~m}$ was composed of organisms having trait modalities as body size of $10-100 \mathrm{~mm}$, life span of 1-2/3-10 years, epizoic/swim mobility, suspension feeding, mid-depth infauna position, and pelagic-planktotrophic larval development. Although substations T1, T2 and D2 were shallow, they showed greater similarity to deep substations in terms of trait characteristics. This similarity may be related to the high abundance of Upogebia and Brachynotus at these stations. "Pelagic-lecithotrophic" larval development, "sexual/ brood eggs" reproduction type, and "subsurface" feeding modes were clearly distinguished at substations $\mathrm{T} 1, \mathrm{~T} 2$, and $\mathrm{D} 2$, particularly in winter.

According to the results of the present study, macrobenthic assemblages along the SSA can be defined by the dominance of several taxa. Two distinct benthic communities and functional classes were identified with respect to depth. The depth range of 0-60 m was characterized by bivalves (Chamelea, Pitar), some polychaetes (Spionidae, Paraonidae, Capitellidae) and crustaceans (Upogebia, Diogenes, Crangon). The depth range below $60 \mathrm{~m}$ is characterized by Amphiura from echinoderms, by Abra from bivalves, and by some other polychaete species. The dominant functional structure along the affected SSA reflects the functional character of the dominant taxa, in particular Chamelea and Amphiura.

Consequently, it can be concluded that the SSA has different benthic communities and functional composition at depths below and above $60 \mathrm{~m}$. Bivalves, polychaetes, and crustaceans with the traits of small/medium size, suspension feeding, self-burying and bioturbating represented communities within 
$<60 \mathrm{~m}$. Assemblages below $60 \mathrm{~m}$ depth were characterized by the presence of Amphiura, polychaetes and some bivalves (Abra-Papillicardium) with dominant traits of a medium/large body and diffusive mixers, free-living and subsurface deposit-feeding behavior.

It can be concluded that the depth range of 0-60 $\mathrm{m}$ is functionally specialized. This zone is dominated by opportunistic life history traits that have developed in response to anthropogenic pressure, especially with the widespread distribution of bivalve groups. In fact, there are studies reporting that suspension feeding is the dominant trait in areas with low levels of disturbance from trawling (Tillin et al. 2006). At first glance, the dominance of filter-feeding organisms in the affected area can be considered interesting, but most bivalves occurring at $0-40 \mathrm{~m}$ in the SSA feeding on suspended solids were those that exhibit typical burrowing behavior and can be active in shallow/ deep locations of infauna. In other words, only those bivalve species that can live in the sediment were able to survive under trawl pressure in the benthic habitat of the SSA. In fact, bivalves in this area feed on deposit/interphase/suspension through their ctenidia and siphons, and in this sense they show different characteristics from those that feed by filtering the water column. Thus, it can be concluded that the structure of the benthic macrofauna in the SSA is resistant to disturbance and the benthos is moderately sensitive to trawl pressure, depending on the type of functional indicator trait and the group of organisms.

In general, organisms can develop a response to trawling disturbance through the larval development strategy, reproductive type, and sediment position-related behavior. The adoption of the planktotrophic trait by pelagic egg development and larval development strategy represents the long-term vulnerability, in other words, the ability of taxa to re-colonize in a trawled area (Bolam et al. 2013). For example, the larval type of an organism is a reflection of its adaptation to environmental change. Taxa characterized by planktotrophic larval development have higher dissemination potential and less risk of extinction than other development types (McHugh \& Fong 2002). Organisms inhabiting shallow sediment layers interact more with trawl gear than those living in deep sediment layers. Jennings and Kaiser (1998) found that biogenic habitats and mud sediments are less exposed to natural disturbance caused by wave movements and bottom currents, and are generally more affected by fisheries, resulting in long-term ecosystem changes. On the contrary, Prantoni et al. (2013) and Sciberras et al. (2013) reported that soft-bottom habitats are highly exposed to natural physical disturbance and are usually less affected by fisheries. Tillin et al. (2006) showed that there is no clear change in the functional community composition between localities in the Dogger Bank (North Sea) area exposed to different levels of trawling intensity. Researchers concluded that the Dogger Bank community was able to adapt to a high degree of natural disturbance due to currents and waves. In addition to low sensitivity traits evolving as a response to fisheries impact, traits such as long life span and suspension feeding are also present in the SSA. SSA communities appear to be adapted to the impact of long-term bottom and beam trawling at depths of $0-60 \mathrm{~m}$.

Traits that contribute to the variability of benthic communities in the SSA include maximum size, sediment position, larval development strategy, living habit, and reproduction type. Benthic communities are mostly governed by life history and behavioral characteristics. Bioturbation and morphological traits are weakly correlated with FCA axes. This is because only one of the categories in both traits of bioturbation and morphology is homogeneously dominant over the others. Taxa with an exoskeleton dominate within the the benthic communities. For example, in taxa with different levels of susceptibility to trawling, the morphological trait "exoskeleton" provides protection against pressure, since its relative sensitivity to the impact of trawling is quite low. Morphology can shift toward the trait of exoskeleton, especially in areas under severe fishing pressure. Bolam et al. (2013) assigned each trait a score (ranging from 1 to 10) and qualified the exoskeleton trait with a score 1-2, which implies low sensitivity. Bioturbation in the SSA is mainly represented by the "diffusive-mixer" or "surface-deposition" taxa. The bioturbation activity of taxa affects the penetration of oxygen deep into the sediment. Some organisms provide oxygenation to deep layers by burrowing the sediment and create an available environment for other organisms that cannot obtain dissolved oxygen from the sediment (Levinton 1995). Paganelli et al. (2012) reported that "surface-deposit" species correlated negatively with the percentage of mud, whereas "diffusive-mixer" species correlated positively with the sediment type. They also found that "surface-deposit" taxa could directly affect the ratio of fine particles in the sediment. Such a relationship can also be mentioned in the current research area. According to the results from this study, the area can be divided into shallow sandy-mud habitats (infralittoral and shallow circalittoral soft bottom biozones) dominated by "surface-deposit bivalves", and deep mud-sand habitats (shallow and deep circalittoral soft bottom 
biozones) with a "diffusive-mixer Amphiura-Abrapolychaete community". Depth may be the main factor affecting the functional distribution of the macrobenthic community. Kun et al. (2019) found that sediment composition and depth are the main factors that affect the distribution of the functional structure of macrobenthos in the Bering Sea. Biodeposition activity is pronounced at a depth of $0-40 \mathrm{~m}$, where bivalves are more dominant. They can enrich the sediment by filtering suspended particles from the sediment-water interface and by ejecting particles. Bivalves increase the ratio of particle accumulation on the seabed and stimulate the microbial production (Newell 2004). Filter-feeding bivalves can remove 60\% to $90 \%$ of the suspended organic matter from the horizontal particle stream depending on the sediment size (Loo \& Rosenberg 1989). The reduction in biomass of this group can change the pattern of resource use and energy flow across the benthic ecosystem (Tillin et al. 2006). Amphiura and Abra inhabiting depths below $60 \mathrm{~m}$ are defined as "biodiffusers". Such species can consume fine particles and bring them to the surface, creating a new substrate. Some macrobenthic species play an important role in the ecological process, as they can alter the environment. For example, the type of mobility in burrowing activity has a major effect on sediment. Burrowing taxa can increase the oxygen level at the bottom or affect the organic matter concentration (Aller 1982; Rhoads \& Boyer 1982). These organisms provide mixing in the upper few centimeters of the sediment. Gilbert et al. (2007) found that Amphiura and Abra are effective bioturbators (795 ind. $\mathrm{m}^{-2}$ ) that mix the sediment to a depth of 3-4 $\mathrm{cm}$. One individual of the species Amphiura filiformis can oxidize $35 \mathrm{~cm}^{2}$ of surface sediment (3 cm deep) by using its arms in the sediment-water interface (Ockelmann \& Muus 1978). Polychaetes distributed at almost any depth are gallery-biodiffusers. These organisms can be effective to a depth of 10 to $30 \mathrm{~cm}$ through tunnels, channels or pits they dig in the sediment. The biodiffusion coefficient for populations of these surface deposit-feeding taxa is 1 to $2 \mathrm{~cm}^{2}$ years ${ }^{-1}$ (Quintana et al. 2007). Bioturbation by a U-shaped tube burrower and gallery-diffuser can increase microbial respiration up to $250 \%$ at the water-sediment interphase of diffusion-dominated systems (Mermillod-Blondin et al. 2008). In such a system, the production and water transmission to the sediment by deep burrowers can increase the water flow in the sediment by up to $2000 \%$ (Mermillod-Blondin 2011).

In the spring period, $\mathrm{K} 4$ and $\mathrm{C} 1$ stations differed in terms of bioturbation with the formation of a conveyor belt. Organisms belonging to the Capitellidae family, which is one of the most common groups among polychaetes in the area, transport particles from certain depths of the sediment to the sediment surface by digging in a head-down position (upward conveyors). Although bioturbation activity varies with the density of taxa, it is unclear how effective this trait is in the area. Biodeposition and bioturbation are two important ecosystem engineering functions. Although biodeposition is considered as bioturbation in other studies, it is categorized separately from bioturbation (Mermillod-Blondin 2011). Bioturbation activity can play an important role in diffusion-dominated habitats, and the effect of this activity is stronger than in advection-dominated habitats. The effects of invertebrates on sediment properties and hydrological changes in diffusion-dominated habitats are quite significant. In these areas, characterized by sandy/ muddy sediments, invertebrates act as 'direct drivers' of water and materials (Mermillod-Blondin 2011). Feeding traits can generate differences in ecosystem functioning. The surface deposit-, subsurface deposit-, and suspension-feeding types in the SSA allow the organic matter to be suspended in the water column as the main food source and to be stored in the sediment. Since the food supply for macrobenthic species in both groups (deposit and suspension feeders) is different, energy flow can have separate paths in both systems.

The SSA, which is under high fishing pressure, appears to be dominated by filter-feeding and deposit-feeding taxa. It can be concluded that scavenger feeding is negatively affected in extensively trawled areas. This may be due to the fact that fish that are top predators have long been removed from the environment. Reduced predation and competition with filtering and deposit-feeding organisms may have resulted in their dominance in the ecosystem. However, fish predation does not affect benthos in bottom-up systems (van Denderen et al. 2013). It is also unclear whether there is only one dominant form of trophic control in soft-bottom benthic ecosystems (Wilson 1991). There are indications of increased abundance of epifauna and scavenging fish in trawled areas, but this response has been poorly demonstrated in opportunistic macrofaunal scavengers (Frid at al. 2000). Although there are no dominant scavenging fish species in the SSA to represent such an effect, observations from our other studies have shown that epifaunal crab species (Liocarcinus depurator and $L$. navigator) are highly abundant in the area (KARTIRP 2020). Once the trawling operation is finished, active fish and epifauna that want to take advantage of the discarded catch quickly arrived in a trawled area (Kaiser \& Spencer 1996). This may reduce opportunities 
for small benthic infauna seeking an additional food source. Therefore, discards after the towing process may not have a significant impact on scavenging infauna.

The body size trait plays an important role in the SSA and is highly correlated with the FCA axes. Bergmann \& Hup (1992) found that large individuals of Lanice spp. and some echinoids are less sensitive to fishing activities than small individuals. This is because the ability of large individuals to form deep tubes allows them to escape. This is the case with polychaetes, whose density in the SSA increased at depths below $40 \mathrm{~m}$. The size distribution was observed to be wide, especially for the genera Melinna and Terebellides, which can form muddy tubes. Large organisms play a particularly important role in the rate of sediment processing. Typically, zoobenthos increase the exchange of particles between water and sediment. In soft sediments, large organisms influence the community and local environmental characteristics by changing hydrodynamics and biogeochemical and particle gradients within the sediment (Thrush et al. 2006). Bremner et al. (2003) found that the "body size" as a variable is less useful than other biological traits in determining changes in marine community composition in the English Channel and the North Sea. According to Reizopoulou \& Nicolaidou (2007), on the other hand, the body size is an effective tool to assess changes in a community.

As this study is the first attempt to determine functional structure using biological traits of macrozoobenthos in the SSA in the southern Black Sea, there are no direct references on this topic. However, there are studies that contain valuable information on the macroinfauna representatives identified in the present study that contribute to the current results.

Chamelea gallina and Pitar rudis from the mollusca group are the most dominant taxa in the SSA within the depth range of $0-20 \mathrm{~m}$, which is characterized by soft-bottom structure. In the study conducted by Sezgin et al. (2010) on the Southern Black Sea coast, it was found that Chamelea gallina (69\%) and Pitar rudis $(64 \%)$ were the most common bivalve species at 39 localities.

Polychaetes, as the most diverse group of invertebrates, were represented in the study area by 14 different taxa, contributing significantly to both biomass and abundance following the bivalves. Paraonidae, Capitellidae, Terebellides, Nephtys, Micronephthys and Melinna are the most common taxa. These taxa occur in all depth layers. Due to the extremely wide adaptability of polychaetes, these organisms are found at all depths (except the anoxic zone) and in all substrate types in the Black Sea. Based on the available literature on polychaetes, Sahin and Cinar (2012) reported that 238 valid species belonging to 45 families occur in the Black Sea. They found that the highest number of species $(n=119)$ inhabited the sandy bottom, and the lowest number of species ( $n=7$ species) was observed on sponges.

Surugiu (2011) grouped polychaetes according to their vertical distribution in his study area on the Romanian coast, involving all types of substrates and depth ranges from the littoral zone to $210 \mathrm{~m}$. In recent years, polychaetes have proven to be a good indicator of marine environment quality (Surugiu 2000, 2005, 2009; Surugiu \& Feunteun 2008).

The main opportunistic species in the Black Sea include Alitta succinea, Polydora cornuta, Polydora websteri and Capitella capitata (Surugiu 2005, 2009; Surugiu \& Feunteun 2008). Perinereis cultrifera, Nereis zonata, Syllis gracilis, Syllis hyalina, Eulalia clavigera and Nereiphylla rubiginosa are given as examples of sensitive species in the Black Sea ecosystem (Surugiu 2005, 2009; Surugiu \& Feunteun 2008). Many polychaetes contribute to natural self-purification activity. For example, Gomoiu (1982) showed that Mellina palmata populations on the Black Sea shelf in Romania can process $4.8-9.6 \mathrm{~kg}$ of mud per $\mathrm{m}^{2}$ per day.

Man-driven factors such as eutrophication, overfishing, and introduction of invasive species have caused changes in the Black Sea ecosystem (Daskalov 2003, 2008; Oguz et al. 2012). Fishing pressure and overfishing are some of the biggest problems for the SSA. Major ecosystem changes are inevitable in this area that has been exposed to fishing gear pressure for many years. According to the results of this study, the functional profile of the SSA is the result of adaptation to pressure factors, especially fishing disturbance. The present situation is possibly a form of reconstruction of the benthic structure devastated for many years. It can be concluded that the benthic infauna structure in the SSA is resistant, and considering the functional structure of the area, species showing moderate sensitivity to mechanical stress occur in the area.

\section{Acknowledgements}

We thank Dr. Serdar SÜER and Dr. Melih RÜZGAR for their contribution to the sampling process.

\section{Funding}

This study was funded by WP3 of the EU Project, FP7 BENTHIS (312088). 


\section{References}

Aller, R. C. (1982). The effects of macrobenthos on chemical properties of marine sediment and overlying water. In Animal-sediment relations (pp. 53-102). Springer US.

Beauchard, O., Veríssimo, H., Queirós, A.M. \& Herman, P.M.J. (2017). The use of multiple biological traits in marine community ecology and its potential in ecological indicator development. Ecological Indicators 76: 81-96.

Beaumont, N.J. \& Tinch, R. (2003). Goods and services related to the marine benthic environment. Centre for Social and Economic Research on the Global Environment Working Paper, ECM 03-14. ISSN 0967-8875.

Bergmann, M.J.N. \& Hup, M. (1992). Direct effects of beam trawling on macrofauna in a sandy sediment in the southern North Sea. ICES Journal of Marine Science 49(1): 5-11.

Bolam, S.G. (2012). Impacts of dredged material disposal on macrobenthic invertebrate communities: a comparison of structural and functional (secondary production) changes at disposal sites around England and Wales. Marine Pollution Bulletin 64(10): 2199-2210.

Bolam, S.G., Coggan, R.C., Eggleton, J.E., Diesing, M. \& Stephens, D. (2013). Sensitivity of macrobenthic secondary production to trawling in the English sector of the Greater North Sea: a biological traits approach. Journal of Sea Research 85: 162-177.

Bolam, S.G. \& Eggleton, J.D. (2014). Macrofaunal production and biological traits: Spatial relationships along the UK continental shelf. Journal of Sea Research 88: 47-58.

Bolam, S.G., Coggan, R.C., Eggleton, J.E., Diesing, M. \& Stephens, D. (2014). Sensitivity of macrobenthic secondary production to trawling in the English sector of the Greater North Sea: a biological traits approach. Journal of Sea Research 85: 162-177.

Bremner, J., Frid, C.L.J. \& Rogers, S.I. (2003). Assessing marine ecosystem health: the long-term effects of fishing on functional biodiversity in North Sea benthos. Aquatic Ecosystem Health \& Management 6(2): 131-137.

Bremner, J., Frid, C.L.J. \& Rogers, S.I. (2005). Biological traits of the North Sea benthos: does fishing affect benthic ecosystem function? In American Fisheries Society Symposium Vol. 41, p. 477, American Fisheries Society.

Bremner, J., Rogers, S. I. \& Frid, C. L. J. (2006). Methods for describing ecological functioning of marine benthic assemblages using biological traits analysis (BTA). Ecological Indicators 6(3): 609-622.

Bremner, J. (2008). Species traits and ecological functioning in marine conservation and management. Journal of Experimental Marine Biology and Ecology 366(1): 37-47.

Cesar, C.P. \& Frid, C.L.J. (2009). Effects of experimental smallscale cockle (Cerastoderma edule L.) fishing on ecosystem function. Marine Ecology 30(1): 123-137. ISSN 0173-9565.

Chevenet, F., Doledec, S. \& Chessel, D. (1994). A fuzzy-coding approach for the analysis of long-term ecological data. Freshwater Biology 31(3): 295-309.

Clarke, K.R. \& Warwick, R.M. (1994). An approach to statistical analysis and interpretation. Change in Marine Communities. Natural Environment Research Council, Plymouth, 2.

Daskalov, G.M. (2003). Long-term changes in fish abundance and environmental indices in the Black Sea. Marine Ecology Progress Series 255: 259-270.

Daskalov, G.M. (2008). Overfishing affects more than fish populations: trophic cascades and regime shifts in the Black Sea (pp. 418-433). Oxford, UK: Blackwell Publishing Ltd..

Darr, A., Gogina, M. \& Zettler, M.L. (2014). Functional changes in benthic communities along a salinity gradient a western Baltic case study. Journal of Sea Research 85: 315-324.

Doledec, S. \& Statzner, B. (1994). Theoretical habitat templets, species traits, and species richness: 548 plant and animal species in the Upper Rhone River and its floodplain. Freshwater Biology 31: 523-538.

Donadi, S., Eriksson, B.K., Lettmann, K.A., Hodapp, D., Wolff, J.O. \& Hillebrand, H. (2015). The bodysize structure of macrobenthos changes predictably along gradients of hydrodynamic stress and organic enrichment. Marine Biology 162(3): 675-685. DOI: :10.1007/s00227-015-2614-z.

Dray, S., Choler, P., Doledec, S., Peres-Neto, P.R., Thuiller, W. et al. (2014). Combining the fourth-corner and the RLQ methods for assessing trait responses to environmental variation. Ecology 95(1): 14-21.

Frid, C.L.J., Harwood, K.G., Hall, S.J. \& Hall, J.A. (2000). Long-term changes in the benthic communities on North Sea fishing grounds. ICES Journal of Marine Science 57(5): 1303-1309.

Frid, C.L.J. (2011). Temporal variability in the benthos: does the sea floor function differently over time. Journal of Experimental Marine Biology and Ecology 400(1): 99-107.

Gilbert, F., Rivet, L. \& Bertrand, J.C. (1994). The fate of petroleum hydrocarbons in marine sediments: influence of the burrowing polychaete Nereis diversicolor. Chemosphere 29: $1-12$.

Gilbert, F., Hulth, S., Grossi, V., Poggiale, J.C., Desrosiers, G. et al. (2007). Sediment reworking by marine benthic species from the Gullmar Fjord (Western Sweden): importance of faunal biovolume. Journal of Experimental Marine Biology and Ecology 348(1): 133-144.

Gogina, M., Darr, A. \& Zettler, M.L. (2014). Approach to assess consequences of hypoxia disturbance events for benthic ecosystem functioning. Journal of Marine Systems 129: 203-213.

Gomoiu, M.T. (1982). On the populations of Melinna palmata Grube at the romanian littoral of the Black Sea. Cercetări marine 15: 115-131.

Jennings, S. \& Kaiser, M.J. (1998). The effects of fishing on marine ecosystems. Advances in Marine Biology 34: $201-$ 352.

Kaiser, M.J. \& Spencer, B.E. (1996). The effects of beam-trawl 
disturbance on infaunal communities in different habitats. Journal of Animal Ecology 65(3): 348-358.

KARTRIP (2020). Monitoring of Trawl Fisheries in The Black Sea, project number: TAGEM/ HAYSUD/2010/09/01/04. Fisheries Management (A09. P-01).

Kun, L., Heshan, L., Xuebao, H., Yaqinb, H., Zhong, L. et al. (2019). Functional trait com-position and diversity patterns of marine macrobenthos across the Arctic Bering Sea. Ecological Indicators. 102: 673-685. DOI: 10.1016/j. ecolind.2019.03.029.

Levinton J. (1995) Bioturbators as ecosystem engineers: control of the sediment fabric, inter-individual interactions, and material fluxes. In C.G. Jones \& J.H. Lawton (Eds.), Linking Species \& Ecosystems (pp. 29-36). Boston, MA: Springer

Loo, L.O. \& Rosenberg, R.(1989). Bivalve suspensionfeeding dynamics and benthic-pelagic coupling in an eutrophicated marine bay. Journal of Experimental Marine Biology and Ecology 130(3): 253-276.

McHugh, D. \& Fong, P.P. (2002). Do life history traits account for diversity of polichaete anellids? Invertebrate Biology 121(4): 325-338.

Mermillod-Blondin, F., Nogaro, G., Vallier, F. \& Gibert, J. (2008). Laboratory study highlights the key influences of stormwater sediment thickness and bioturbation by tubificid worms on dynamics of nutrients and pollutants in stormwater retention systems. Chemosphere 72(2): 213223.

Mermillod-Blondin, F. (2011). The functional significance of bioturbation and biodeposition on biogeochemical processes at the water-sediment interface in freshwater and marine ecosystems. Journal of the North American Benthological Society 30(3): 770-778.

Munari, C. (2013). Benthic community and biological trait composition in respect to artificial coastal defence structures: a study case in the northern Adriatic Sea. Marine environmental research 90: 47-54.

Muntadas, A., de Juan, S. \& Demestre, M. (2015). Integrating the provision of ecosystem services and trawl fisheries for the management of the marine environment. Science of The Total Environment 506: 594-603.

Nasi, F., Nordström, M.C., Bonsdorff, E., Auriemma, R., Cibic, T. et al. (2018). Functional biodiversity of marine soft-sediment polychaetes from two Mediterranean coastal areas in relation to environmental stress. Marine environmental research 137: 121-132.

Newell, R.I.E. (2004). Ecosystem influences of natural and cultivated populations of suspension-feeding bivalve molluscs: a review. Journal of Shellfish Research 23(1): 51-62.

Ockelmann, K.W. \& Muus, K. (1978). The biology, ecology and behaviour of the bivalve Mysella bidentata (Montagu). Ophelia 17(1): 1-93.

Oguz, T., Akoglu, E. \& Salihoglu, B. (2012). Current state of overfishing and its regional differences in the Black Sea.
Ocean \& coastal management 58: 47-56.

Oug, E., Fleddum, A., Rygg, B. \& Olsgard, F. (2012). Biological traits analyses in the study of pollution gradients and ecological functioning of marine soft bottom species assemblages in a fjord ecosystem. Experimental Marine Biology and Ecology 432: 94-105.

Paganelli, D., Marchini, A. \& Occhipinti-Ambrogi, A. (2012). Functional structure of marine benthic assemblages using Biological Traits Analysis (BTA): a study along the Emilia-Romagna coastline (Italy, North-West Adriatic Sea). Estuarine, Coastal and Shelf Science 96: 245-256.

Prantoni, A.L., Da Cunha Lan, P., Sandrini-Neto, L., Filho, O.A.N. \& De Oliveira, V.M. (2013). An experimental evaluation of the short-term effects of trawling on infaunal assemblages of the coast off southern Brazil. Journal of the Marine Biological Association of the UK. 93(02): 495-502.

Quintana, C.O., Tang, M. \& Kristensen, E. (2007). Simultaneous study of particle reworking, irrigation transport and reaction rates in sediment bioturbated by the polychaetes Heteromastus and Marenzelleria. Journal of Experimental Marine Biology and Ecology. 352(2): 392-406.

Reizopoulou, S. \& Nicolaidou, A. (2007). Index of size distribution (ISD): a method of quality assessment for coastal lagoons. In Lagoons and Coastal Wetlands in the Global Change Context: Impacts and Management Issues (pp. 141-149). Springer Netherlands.

Rhoads, D.C. \& Boyer, L.F. (1982). The effects of marine benthos on physical properties of sediments. In Animal-sediment relations (pp. 3-52). Springer US.

Sahin, G.K. \& Cinar, M.E. (2012). A check-list of polychaete species (Annelida: Polychaeta) from the Black Sea. Journal of Black Sea/Mediterranean Environment 18(1): 10-48.

Sciberras, M., Hinz, H., Bennell, J.D., Jenkins, S.R., Hawkins, S.J. et al. (2013). Benthic community response to a scallop dredging closure within a dynamic seabed habitat. Marine Ecology Progress Series 480: 83 - 98.

Surugiu, V. (2000). Des modifications survenues dans la structure des populations des Annélides Polychètes d'Agigea dans les 30 dernières années. Analete Stiintifice ale Universitatii" Al. I. Cusa" Iasi, s. Biologie animala 46: 7381.

Surugiu, V. (2005). The use of polychaetes as indicators of eutrophication and organic enrichment of coastal waters: A study case - Romanian Black Sea coast. Analete Stiintifice ale Universitatii "Al. I. Cusa" lasi, s. Biologie animala. 51: 5562.

Surugiu, V. \& Feunteun, M. (2008). The structure and distribution of polychaete populations influenced by sewage from the Romanian Black Sea coast. Analete Stiintifice ale Universitatii "Al. I. Cusa" lasi, s. Biologie animala. 54: 177-184.

Surugiu, V. (2009). The influence of sewage pollution on polychaetes associated to mussel beds of Romanian Black Sea coast. Geo-Eco-Marina 15: 77-87. 
Surugiu, V. (2011). Polychaete research in the Black Sea. Romanian Journal of Aquatic Ecology 1(1): 101-122.

Solan, M., Batty, P., Bulling, M.T. \& Godbold, J.A. (2008). How biodiversity affects ecosystem process: implications for ecological revolutions and benthic ecosystem function. Aquatic Biology 2: 289-301.

Thrush, S.F., Hewitt, J.E., Gibbs, M., Lundquist, C. \& Norkko, A. (2006). Functional role of large organisms in intertidal communities: community effects and ecosystem function. Ecosystems 9(6): 1029-1040.

Tillin, H.M., Hiddink, J.G., Jennings, S. \& Kaiser, M.J. (2006). Chronic bottom trawling alters the functional composition of benthic invertebrate communities on a sea-basin scale. Marine Ecology Progress Series 318: 31-45.

Usseglio-Polatera, P., Bournaud, M., Richoux, P. \& Tachet, H. (2000). Biomonitoring through biological traits of benthic macroinvertebrates: how to use species trait databases? In Assessing the Ecological Integrity of Running Waters. Springer Netherlands 153-162.

van Denderen, P.D., van Kooten, T. \& Rijnsdorp, A.D. (2013). When does fishing lead to more fish? Community consequences of bottom trawl fisheries in demersal food webs. Proceedings of the Royal Society of London B: Biological Sciences. 280(1769): 20131883.

van der Linden, P., Patrício, J., Marchini, A., Cidc, N., Netoa, J.M. et al. (2012). A biological trait approach to assess the functional composition of subtidal benthic communities in an estuarine ecosystem. Ecological Indicators 20: 121133.

van Son, T.C., Oug, E., Halvorsen, R.\&Melsom, F. (2013). Gradients in traits composition and their relation to environmental complex-gradients and structuring processes: a study of marine sediment species communities. The Open Marine Biology Journal 7: 14-27.

Villnäs, A., Norkko, J., Lukkari, K., Hewitt, J. \& Norkko, A. (2012). Consequences of increasing hypoxic disturbance on benthic communities and ecosystem functioning. PLOS One 7(10): e44920. DOI: 10.1371/journal.pone.0044920.

Wan Hussin, W.M.R., Cooper, K.M., Frojan, C.R.S.B., Defew, E.C. et al. (2012). Impacts of physical disturbance on the recovery of a macrofaunal community: a comparative analysis using traditional and novel approaches. Ecological Indicators 12(1): 37-45.

Wilson, W.H. (1991). Competition and predation in marine soft-sediment communities. Annual Review of Ecology and Systematics 21: 221-241. 
Supplementary material

Fuzzy-scored biological traits for macrobenthic taxa in SSA

\begin{tabular}{|c|c|c|c|c|c|c|c|c|c|c|c|c|c|c|c|c|c|c|c|c|c|c|c|c|c|c|c|c|c|c|c|c|c|c|c|c|c|c|c|c|c|c|c|}
\hline & & & $s$ & & & & & |vi & & & & & & & & U. & & & & & & & LF & & & & & & & & & $\mathrm{FN}$ & & & & & lob & & & & & & \\
\hline Kategori & 1 & & 3 & 5 & 0 & 1 & 2 & 3 & & & \begin{tabular}{l|l}
6 & 1 \\
\end{tabular} & 2 & & \begin{tabular}{|l|l} 
\\
\end{tabular} & 1 & & \begin{tabular}{l|l}
3 & 1 \\
\end{tabular} & & & 4 & 1 & 2 & 3 & & 5 & 6 . & 12 & & & 1 & 2 & & & & & $\begin{array}{ll}1 & 2 \\
\end{array}$ & & $4 \mid$ & & $2=$ & & & \\
\hline Terebellic & & & 3 & 0 & & 3 & 0 & 0 & 0 & 1 & 00 & 1 & & 0 & 0 & & 30 & $\begin{array}{ll}0 & 0 \\
0\end{array}$ & & 0 & 3 & 0 & 0 & 0 & 0 & 0 & 30 & 0 & 0 & 0 & 3 & 0 & 0 & & & $\begin{array}{ll}10 \\
\end{array}$ & 0 & 0 & 1 & 1 & & & \\
\hline Nephtys & & & 3 & 0 & 0 & 3 & 0 & 0 & 0 & ) & 0 & 0 & 2 & 0 & 3 & ( & 0 & 0 & 0 & 0 & 0 & 0 & 3 & 0 & 0 & 0 & 3 & 1 & 0 & 0 & 0 & 0 & 3 & 3 & 0 & 02 & 0 & 3 & & 0 & 0 & & \\
\hline Phyllodoce & & & 0 & 2 & 2 & 3 & 0 & 0 & 0 & t & $\begin{array}{l}0 \\
0\end{array}$ & 0 & 1 & 0 & 3 & & $\begin{array}{lll}0 & 0 \\
0\end{array}$ & \begin{tabular}{l|l}
0 & 3 \\
\end{tabular} & 0 & 0 & 0 & 0 & 3 & 0 & $0 \mathrm{c}$ & 0 & 10 & 0 & 0 & 0 & 0 & 0 & & & 0 & $\begin{array}{lll}0 & 0 \\
\end{array}$ & 1 & 0 & 0 & 1 & 0 & & \\
\hline Palaeonem & & & 1 & 0 & 0 & 3 & 0 & 0 & 0 & ) & 00 & 3 & 2 & 0 & 3 & 3 & 30 & 03 & 3 & 0 & 0 & 0 & 3 & 0 & 0 & 0 & 3 & 1 & 0 & 0 & 0 & 0 & 2 & 30 & 0 & 00 & 3 & 0 & & 1 & 0 & & \\
\hline Paraonidae & & & 3 & 0 & 0 & 3 & 0 & 0 & 0 & ) & $\begin{array}{l}0 \\
0\end{array}$ & 1 & 1 & 0 & 0 & 0 & 10 & \begin{tabular}{l|l}
0 & 0 \\
0
\end{tabular} & 0 & 2 & 0 & 0 & 3 & 0 & $0 \mathrm{c}$ & 0 & 3 & 0 & 0 & 0 & 2 & 1 & & & $\begin{array}{l}0 \\
0\end{array}$ & $\begin{array}{ll}0 & 0 \\
\end{array}$ & 0 & 1 & 1 & $0 \mid c$ & $\begin{array}{lll}0 & 0\end{array}$ & & \\
\hline Capitella & & & 3 & 30 & 0 & 3 & 0 & 0 & 0 & ) & 00 & 1 & 0 & 0 & 3 & 3 & 30 & 00 & 1 & 3 & 3 & 1 & 0 & 0 & 0 & 0 & 3 & 0 & 0 & 0 & 0 & 3 & 0 & 0 & $\begin{array}{ll}0 & 1\end{array}$ & 10 & 0 & 0 & & 0 & 10 & & \\
\hline Capitellidae & 0 & & 3 & 3 & 0 & 3 & 0 & 0 & 0 & ) & $\begin{array}{l}0 \\
0\end{array}$ & 1 & 0 & 0 & 1 & 1 & \begin{tabular}{l|l}
1 & 0 \\
\end{tabular} & \begin{tabular}{l|l}
0 & 1 \\
\end{tabular} & 1 & 3 & 3 & 3 & 1 & 0 & 0 & 0 & 3 & 0 & 0 & 0 & 0 & 3 & 0 & & & \begin{tabular}{l|l}
1 & 0 \\
\end{tabular} & 0 & 0 & 0 & \begin{tabular}{|l|l}
0 & 1 \\
\end{tabular} & 10 & & \\
\hline Nereis & & & 3 & 3 & 0 & 3 & 0 & 0 & 0 & ) & 00 & 0 & 1 & 0 & 0 & & 30 & 03 & 0 & 0 & 0 & 1 & 0 & 0 & $0 \mathrm{c}$ & 0 & 11 & 1 & 1 & 1 & 3 & 0 & 3 & 30 & & 00 & 1 & 1 & & 0 & $\begin{array}{ll}0 & 1\end{array}$ & & \\
\hline Melinno & 0 & & 0 & 0 & 0 & 3 & 0 & 0 & 0 & ) & $\begin{array}{l}0 \\
0\end{array}$ & 3 & 0 & 0 & 0 & 3 & $\begin{array}{lll}0 & 0 \\
\end{array}$ & $\begin{array}{ll}0 & 2 \\
& \end{array}$ & 0 & 0 & 3 & 0 & 0 & 0 & $0 \mathrm{c} c$ & 0 & 2 & 0 & 0 & 0 & 3 & 0 & 0 & & o 1 & $\begin{array}{l}1 \\
1\end{array}$ & 0 & 0 & 0 & 10 & $\begin{array}{ll}0 & 0\end{array}$ & & \\
\hline Micro & & & 3 & 10 & 0 & 3 & & 0 & 0 & & 00 & 0 & 2 & 0 & 3 & & 00 & 03 & 0 & 0 & 0 & 0 & 3 & 0 & 0 & & 3 & 1 & 0 & 0 & 0 & 0 & & & & $\begin{array}{ll}02 \\
0\end{array}$ & 0 & 3 & & 0 & 00 & & \\
\hline Lineidae & 0 & & 0 & 0 & 2 & 3 & 0 & 0 & 0 & ) & $\begin{array}{l}0 \\
0\end{array}$ & 0 & 1 & 0 & 0 & 0 & \begin{tabular}{l|l}
1 & 1
\end{tabular} & $1 \mid 0$ & 1 & 0 & 0 & 0 & 3 & 0 & $0 \mathrm{c} c$ & 0 & 23 & 1 & 0 & 0 & 0 & 0 & 1 & & $\begin{array}{l}0 \\
0\end{array}$ & \begin{tabular}{l|l}
0 & 1 \\
\end{tabular} & 3 & 0 & 1 & 10 & \begin{tabular}{l|l}
0 & 0 \\
\end{tabular} & & \\
\hline Harmoth & 0 & & 3 & 0 & 0 & 3 & 0 & 0 & 0 & 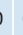 & 00 & 1 & 1 & 0 & 3 & 0 & 00 & 00 & 0 & 3 & 1 & 0 & 3 & 0 & 1 & & 20 & 0 & 0 & 0 & 0 & 0 & 0 & & & 00 & 1 & & & 1 & 00 & & \\
\hline Phoronida & 0 & 0 & 3 & 0 & 0 & 3 & 0 & 0 & 0 & ) & 00 & 1 & 0 & 0 & 3 & 0 & \begin{tabular}{l|l}
0 & 0 \\
0
\end{tabular} & \begin{tabular}{l|l}
0 & 0 \\
\end{tabular} & 0 & 1 & 3 & 0 & 0 & 0 & $0 \mid 1$ & 1 & 11 & 0 & 0 & 3 & 0 & 0 & 0 & & 03 & $\begin{array}{l}3 \\
3\end{array}$ & 0 & 0 & 0 & $\begin{array}{ll}0 & c \\
c\end{array}$ & $0 \mathrm{c}$ & & \\
\hline Upogebia & & & 0 & 30 & 0 & 0 & 0 & 3 & 0 & & 00 & 0 & 3 & 0 & 3 & 0 & 00 & 00 & 0 & 3 & 0 & 3 & 1 & 0 & 0 & & 0 & 0 & 3 & 3 & 3 & 3 & 0 & & & 00 & 3 & & & 3 & & & \\
\hline Brachynotu. & 0 & 0 & 3 & 0 & 0 & 0 & $0 \mid$ & 3 & 0 & ) & 0 & 0 & 1 & 0 & 3 & 0 & \begin{tabular}{l|l}
0 & 0 \\
0
\end{tabular} & \begin{tabular}{l|l}
0 & 0 \\
0
\end{tabular} & 0 & 3 & 0 & 3 & 1 & 0 & $0 \mathrm{c}$ & 0 & 0 & 0 & 3 & 0 & 3 & 3 & 0 & & 0 & $\begin{array}{ll}0 & 0\end{array}$ & 3 & 3 & 3 & $3 \mid c$ & 0 & & \\
\hline Diogenes & & & 0 & 0 & 0 & 0 & 0 & 3 & 0 & & 00 & 0 & 0 & 3 & 3 & 0 & \begin{tabular}{l|l}
0 & 3 \\
\end{tabular} & $\begin{array}{ll}30 \\
0\end{array}$ & 0 & 0 & 0 & 0 & 3 & 0 & 2 & & 0 & 0 & 1 & 2 & 0 & 0 & 0 & & & $\begin{array}{ll}30 \\
\end{array}$ & 0 & 0 & & 0 & & & \\
\hline Amphiura & 0 & 0 & 0 & 0 & 0 & 0 & $0 \mid$ & 3 & 0 & ) & 0 & 0 & 0 & 3 & 3 & 0 & \begin{tabular}{l|l}
0 & 0 \\
0
\end{tabular} & \begin{tabular}{l|l}
0 & 3 \\
\end{tabular} & 0 & 0 & 0 & $0 \mid$ & 3 & 1 & $0 \mathrm{c}$ & 0 & 3 & 0 & 0 & 3 & 3 & 0 & 0 & & 0 & $\begin{array}{ll}0 & 0\end{array}$ & 3 & 3 & 3 & $3 \mid c$ & 0 & & \\
\hline Ampelisca & & & 0 & 0 & 0 & 0 & 0 & 3 & 0 & & 0 & 3 & 0 & 0 & 0 & 0 & 30 & 00 & 0 & 3 & 0 & 1 & 0 & 0 & 0 & & 33 & 0 & 0 & 3 & 3 & 0 & 0 & & & $\begin{array}{ll}0 & 1\end{array}$ & 2 & 1 & & 1 & & & \\
\hline Apseudidae & 3 & 0 & 0 & 0 & 0 & 0 & $0 \mid$ & 3 & 0 & ) & $\begin{array}{ll}0 & 0 \\
0\end{array}$ & 1 & 0 & 0 & 0 & 0 & \begin{tabular}{l|l}
3 & 0
\end{tabular} & $\begin{array}{ll}0 & 0\end{array}$ & 0 & 3 & 0 & 0 & 3 & 3 & 3 c & 0 & 30 & 0 & 0 & 3 & 3 & 0 & 0 & & 0 & $\begin{array}{ll}0 & 0\end{array}$ & 2 & 0 & 0 & \begin{tabular}{|l|l} 
& $c$ \\
\end{tabular} & 0 & & \\
\hline Iphinoe & 3 & & 0 & 0 & 0 & 0 & 0 & 3 & 0 & & 0 & 3 & 0 & 0 & 0 & 0 & 30 & 00 & 0 & 3 & 0 & 1 & 3 & 0 & 0 & & $\begin{array}{ll}3 & 1\end{array}$ & 0 & 0 & 0 & 3 & 0 & 0 & & & $\begin{array}{ll}0 & 3\end{array}$ & 0 & 1 & 1 & 1 & 0 & & \\
\hline Leuconido & 2 & 2 & 0 & 0 & 0 & 0 & $0 \mid$ & 3 & 0 & ) & $\begin{array}{ll}0 & 3 \\
\end{array}$ & 1 & 0 & 0 & 0 & 0 & $\begin{array}{lll}3 & 0\end{array}$ & 0 & 0 & 3 & 0 & $0 \mid$ & 3 & 0 & $0 \mid c$ & 0 & 23 & 0 & 0 & 3 & 0 & 0 & 0 & & 0 & \begin{tabular}{l|l}
0 & 1
\end{tabular} & 3 & 1 & 1 & \begin{tabular}{|l|l}
$\mid$ & $c$
\end{tabular} & 0 & & \\
\hline Cyclope & 3 & 1 & 0 & 0 & 0 & 0 & 0 & 3 & 0 & & 0 & 0 & 1 & 0 & 0 & 0 & 30 & 00 & 3 & 0 & 0 & 0 & 3 & 0 & 0 & & 33 & 0 & 0 & 0 & 3 & 0 & 3 & & & $\begin{array}{ll}0 & 0\end{array}$ & 3 & 3 & & 3 & & & \\
\hline Nassarius & 0 & 3 & 3 & 0 & 0 & 0 & $0 \mid$ & 3 & 0 & ) & 0 & 0 & 0 & 3 & 3 & 0 & \begin{tabular}{l|l}
0 & 0
\end{tabular} & $\begin{array}{l}0 \\
0\end{array}$ & 3 & 0 & 0 & $0 \mid$ & 3 & 0 & 0 & 0 & 30 & 0 & 0 & 0 & 0 & 0 & 3 & & 0 & 0 & 3 & 0 & 0 & $1 \mid c$ & 0 & & \\
\hline Anthozoa & . & 1 & 1 & 1 & 1 & 3 & 0 & 0 & 0 & ) & 00 & 0 & 1 & 0 & 2 & 0 & 13 & $\begin{array}{ll}3 & 3\end{array}$ & 0 & 1 & 0 & 0 & 0 & 0 & 3 & 3 & 30 & 0 & 0 & 3 & 0 & 0 & 0 & & $\begin{array}{l}0 \\
\end{array}$ & $\begin{array}{ll}3 & 0\end{array}$ & 0 & 0 & 0 & 0 & & & \\
\hline Balanus & 0 & 3 & 3 & 0 & 0 & 0 & 0 & 3 & 0 & ) & 0 & 0 & 3 & 0 & 3 & 0 & $\begin{array}{lll}0 & 0\end{array}$ & \begin{tabular}{l|l}
0 & 0
\end{tabular} & 0 & 3 & 0 & 0 & 0 & 0 & 0 & 3 & 30 & 0 & 0 & 3 & 0 & 0 & 0 & & 3 & $\begin{array}{lll}3 & 0\end{array}$ & 0 & 0 & 0 & 10 & 0 & & \\
\hline Chameleo & & 0 & 3 & 0 & 0 & 0 & 0 & 3 & 0 & 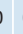 & 00 & 0 & 0 & 3 & 3 & 0 & 00 & $\begin{array}{ll}0 & 3\end{array}$ & 0 & 0 & 0 & 3 & 0 & 0 & 0 & 0 & $\begin{array}{ll}0 & 3\end{array}$ & 0 & 0 & 3 & 0 & 0 & 0 & 0 & $\begin{array}{l}0 \\
0\end{array}$ & $\begin{array}{ll}3 & 0\end{array}$ & 0 & 0 & 0 & 3 & 0 & & \\
\hline Anadd & 0 & 0 & 3 & 0 & 0 & 0 & $0 \mid$ & 3 & 0 & ) & 0 & 0 & 3 & 1 & 3 & 0 & $0 \mid c$ & \begin{tabular}{l|l}
0 & 3
\end{tabular} & 0 & 0 & 0 & $0 \mid$ & 3 & 0 & 0 & 0 & \begin{tabular}{l|l}
1 & 0
\end{tabular} & 0 & 0 & 3 & 0 & 0 & 0 & & $\begin{array}{ll}0 \\
0\end{array}$ & $\begin{array}{ll}3 & 0\end{array}$ & 0 & 0 & 0 & $1 c$ & 0 & & \\
\hline Abra & & 3 & 0 & 0 & 0 & 0 & 0 & 3 & 0 & ) & 00 & 3 & 3 & 0 & 3 & 0 & 0 & 03 & 0 & 0 & 0 & 3 & 0 & 0 & 0 & 0 & 03 & 0 & 0 & 1 & 3 & 3 & 0 & 0 & $\begin{array}{l}0 \\
0\end{array}$ & $\begin{array}{ll}3 & 0\end{array}$ & 0 & 0 & 0 & 1 & 0 & & \\
\hline Pita & 0 & 0 & 3 & 0 & 0 & 0 & 0 & 3 & 0 & ) & 0 & 0 & 1 & 2 & 3 & 0 & $0 \mid c$ & \begin{tabular}{l|l}
0 & 3
\end{tabular} & 0 & 0 & 0 & 3 & 0 & 0 & 0 & 0 & $\begin{array}{ll}0 & 0\end{array}$ & 1 & 0 & 3 & 0 & 0 & 0 & $\begin{array}{lll}0 & 0\end{array}$ & 3 & 0 & 0 & 0 & 1 & $\begin{array}{ll}0 & c\end{array}$ & $0 \mathrm{c}$ & & \\
\hline Donax & 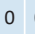 & 0 & 3 & 0 & 0 & 0 & 0 & 3 & 0 & ) & 00 & 0 & 1 & 0 & 3 & 0 & 0 & 03 & 0 & 0 & 0 & 3 & 0 & 0 & 0 & 0 & 00 & 1 & 0 & 3 & 0 & 0 & 0 & 0 & $\begin{array}{l}0 \\
0\end{array}$ & $\begin{array}{ll}30 \\
3\end{array}$ & 0 & 0 & 1 & 1 & 0 & & \\
\hline Mytilus & 0 & 0 & 3 & 0 & 0 & 0 & 0 & 3 & 0 & ) & 0 & 0 & 0 & 1 & 3 & 0 & $0 \mid c$ & \begin{tabular}{l|l}
0 & 3 \\
\end{tabular} & 0 & 0 & 0 & 0 & 0 & 0 & 0 & 3 & \begin{tabular}{l|l}
3 & 0
\end{tabular} & 0 & 0 & 3 & 0 & 0 & 0 & & 3 & $\begin{array}{ll}3 & 0\end{array}$ & 0 & 0 & 0 & 3 & 0 & & \\
\hline Lucinella & 0 & 3 & 0 & 0 & 0 & 0 & 0 & 3 & 0 & ) & 00 & 0 & 1 & 0 & 3 & 0 & 0 & 03 & 0 & 0 & 0 & 2 & 0 & 0 & 0 & 0 & 03 & 0 & 0 & 3 & 0 & 0 & 0 & 0 & $\begin{array}{l}0 \\
0\end{array}$ & $\begin{array}{ll}30 \\
3\end{array}$ & 0 & 0 & 0 & 1 & & & \\
\hline Spisulc & 0 & 0 & 3 & 0 & 0 & 0 & 0 & 3 & 0 & ) & 0 & 0 & 0 & 3 & 3 & 0 & $0(\mathrm{c}$ & \begin{tabular}{l|l}
0 & 3
\end{tabular} & 0 & 0 & 0 & 3 & 0 & 0 & 0 & 0 & \begin{tabular}{l|l}
0 & 3
\end{tabular} & 0 & 0 & 3 & 0 & 0 & 0 & 0 & $\begin{array}{l}0 \\
\end{array}$ & \begin{tabular}{l|l}
3 & 0
\end{tabular} & 0 & 0 & 0 & $1 \mathrm{c}$ & 0 & & \\
\hline Striarca & 0 & 2 & 2 & 0 & 0 & 0 & 0 & 3 & 0 & ) & 00 & 0 & 3 & 0 & 3 & 0 & 0 & 03 & 0 & 0 & 0 & 0 & 3 & 0 & 0 & 0 & $\begin{array}{ll}3 & 1\end{array}$ & 0 & 0 & 3 & 0 & 0 & 0 & 0 & $\begin{array}{l}03 \\
\end{array}$ & $\begin{array}{ll}30 \\
3\end{array}$ & 1 & 0 & 3 & 0 & & & \\
\hline Papillicar & 0 & 3 & 3 & 0 & 0 & 0 & 0 & 3 & 0 & ) & 00 & 0 & 0 & 3 & 3 & 0 & $0(\mathrm{c}$ & $\begin{array}{ll}0 & 3 \\
\end{array}$ & 0 & 0 & 0 & 3 & 0 & 0 & 0 & 0 & $\begin{array}{lll}0 & 0 \\
\end{array}$ & 3 & 0 & 3 & 0 & 0 & 0 & $\begin{array}{l}0 \\
0\end{array}$ & 03 & \begin{tabular}{l|l}
3 & 0
\end{tabular} & 0 & 0 & 0 & $\begin{array}{lll}1 & c \\
c\end{array}$ & 0 & & \\
\hline Gouldia & 0 & 3 & 0 & 0 & 0 & 0 & 0 & 3 & 0 & ) & 00 & 0 & 1 & 2 & 1 & 0 & 0 & 01 & 0 & 0 & 0 & 3 & 0 & 0 & 0 & 0 & 01 & 0 & 0 & 3 & 0 & 0 & 0 & 0 & $\begin{array}{l}0 \\
0\end{array}$ & 10 & 0 & 0 & 0 & 1 & 0 & & \\
\hline Rotaliido & 3 & 0 & 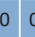 & 0 & 0 & 0 & 0 & 3 & 0 & ) & $\begin{array}{ll}0 & 1 \\
0\end{array}$ & 1 & 0 & 0 & 0 & 0 & 1 & \begin{tabular}{l|l}
1 & 0
\end{tabular} & 1 & 0 & 0 & 1 & 1 & 0 & 1 & 1 & $\begin{array}{lll}1 & 1\end{array}$ & 1 & 0 & 1 & 1 & 0 & 1 & 10 & $\begin{array}{ll}0 \\
0\end{array}$ & \begin{tabular}{l|l}
1 & 0
\end{tabular} & 0 & 0 & 1 & \begin{tabular}{l|l}
1 & $c$ \\
$c$
\end{tabular} & $0 \mathrm{c}$ & & \\
\hline Gammaro & 3 & 0 & 0 & 0 & 0 & 0 & 0 & 3 & 0 & ) & 00 & 3 & 0 & 0 & 0 & 0 & 3 & 00 & 0 & 3 & 3 & 0 & 0 & 0 & 0 & 0 & $\begin{array}{ll}30 \\
3\end{array}$ & 0 & 0 & 0 & 3 & 0 & 0 & 0 & 0 & $\begin{array}{ll}0 & 1\end{array}$ & 2 & 0 & 0 & 1 & 0 & & \\
\hline Crangor & 0 & 0 & $\begin{array}{ll}3 \mid c \\
c\end{array}$ & 0 & 0 & 0 & 0 & 3 & 0 & ) & 00 & 0 & 3 & 0 & 3 & 0 & $0 \mathrm{c}(\mathrm{c}) \mathrm{c}$ & \begin{tabular}{l|l}
0 & 0
\end{tabular} & 0 & 3 & 0 & 0 & 3 & 0 & 0 & 0 & \begin{tabular}{l|l}
3 & 0 \\
\end{tabular} & 0 & 0 & 0 & 0 & 0 & 0 & 3 & 0 & \begin{tabular}{l|l}
0 & 3 \\
\end{tabular} & 0 & 0 & 0 & $1 \mathrm{c}$ & $0 \mathrm{c}$ & & \\
\hline Corophium & 3 & 0 & 0 & 0 & 0 & 0 & 0 & 3 & 0 & ) & 03 & 30 & 0 & 0 & 0 & 0 & 3 & 00 & 0 & 3 & 0 & 3 & 0 & 0 & 0 & 0 & $\begin{array}{ll}13 \\
3\end{array}$ & 0 & 0 & 1 & 3 & 0 & 0 & 0 & 0 & $\begin{array}{ll}0 & 1\end{array}$ & 2 & 1 & 1 & 1 & 0 & 0 & \\
\hline Molgulidae & & 3 & 3 c & 0 & 0 & 0 & 3 & 0 & 0 & ) & 00 & 1 & 1 & 0 & 0 & 1 & $0(\mathrm{c}$ & \begin{tabular}{l|l}
0 & 1
\end{tabular} & 0 & 0 & 0 & 0 & 0 & 3 & 3 & 35 & $\begin{array}{ll}3 & 0\end{array}$ & 0 & 0 & 3 & 0 & 0 & 0 & $\begin{array}{lll}0 & 0\end{array}$ & 3 & $\begin{array}{lll}3 & 0\end{array}$ & 0 & 0 & 0 & $\begin{array}{ll}c \\
\end{array}$ & 0 & 0 & \\
\hline Calyt & 3 & 0 & 0 & 0 & 0 & 0 & 0 & 3 & 0 & ) & 00 & 0 & 1 & 0 & 0 & 0 & 3 & 00 & 0 & 3 & 0 & 0 & 0 & 0 & 0 & 1 & $\begin{array}{ll}3 & 0\end{array}$ & 0 & 0 & 0 & 3 & 0 & 0 & 00 & 0 & $\begin{array}{ll}0 & 0\end{array}$ & 3 & 0 & 0 & 3 & 0 & 0 & \\
\hline Retusidae & 3 & 2 & $\begin{array}{lll}0 & c\end{array}$ & 0 & 0 & 0 & 0 & 3 & 0 & ) & $\begin{array}{ll}0 & 0\end{array}$ & 0 & 1 & 0 & 2 & 0 & 0 & $\begin{array}{lll}0 & 0\end{array}$ & 2 & 0 & 0 & 0 & 2 & 0 & 0 & 0 & 02 & 0 & 0 & 0 & 0 & 0 & 0 & 20 & 0 & $\begin{array}{lll}0 & 0\end{array}$ & 2 & 2 & 2 & $1 \mathrm{C}$ & 0 & 0 & \\
\hline Hydro & 3 & 0 & 0 & 0 & 0 & 0 & 0 & 3 & 0 & ) & 00 & 0 & 3 & 0 & 3 & 0 & 0 & 00 & 3 & 0 & 0 & 0 & 3 & 0 & 0 & 0 & $\begin{array}{ll}30 \\
\end{array}$ & 0 & 0 & 0 & 3 & 0 & 0 & 00 & 0 & $\begin{array}{ll}0 & 0\end{array}$ & 3 & 0 & 0 & 3 & 0 & 0 & \\
\hline Pectinario & 0 & 0 & 1 & 0 & 0 & 3 & 0 & 0 & 0 & ) & 00 & 1 & 1 & 0 & 3 & 0 & 0 c c & $\begin{array}{ll}0 & 3\end{array}$ & 0 & 0 & 3 & 0 & 0 & 0 & 0 & 0 & \begin{tabular}{l|l}
0 & 1
\end{tabular} & 1 & 0 & 0 & 0 & 3 & 0 & $\begin{array}{lll}0 & 0\end{array}$ & $\begin{array}{l}0 \\
0\end{array}$ & \begin{tabular}{l|l}
3 & 0
\end{tabular} & 0 & 0 & 0 & 0 & 3 & 0 & \\
\hline Mystc & 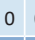 & 0 & 3 & 0 & 0 & 3 & 0 & 0 & 0 & ) & 00 & 1 & 1 & 0 & 1 & 3 & 0 & 03 & 0 & 0 & 0 & 0 & 3 & 3 & 0 & 0 & $\begin{array}{ll}1 & 0\end{array}$ & 0 & 0 & 0 & 0 & 0 & 3 & 3 & 00 & $\begin{array}{ll}0 & 0\end{array}$ & 1 & 0 & 0 & 1 & 0 & 0 & \\
\hline Spionidae & 1 & 1 & 1 & 0 & 0 & 3 & 0 & 0 & 0 & ) & 00 & 1 & 0 & 0 & 3 & 0 & 1 & 12 & 0 & 2 & 3 & 3 & 1 & 0 & 1( & 0 & $\begin{array}{ll}0 & 1\end{array}$ & 0 & 0 & 1 & 3 & 1 & 0 & $\begin{array}{ll}0 & 0 \\
\end{array}$ & \begin{tabular}{l|l}
0 & 1
\end{tabular} & \begin{tabular}{l|l}
1 & 0
\end{tabular} & 0 & 0 & 0 & $1 \mathrm{c}$ & 0 & 0 & 0 \\
\hline Mc & & 0 & 3 & 0 & 0 & 3 & 0 & 0 & 0 & ) & 00 & 0 & 3 & 0 & 3 & 0 & 0 & 03 & 0 & 0 & 0 & 3 & 3 & 0 & 0 & 0 & 03 & 0 & 0 & 2 & 3 & 0 & 0 & 0 & 00 & 00 & 0 & 3 & 3 & 0 & 0 & 0 & \\
\hline Acanthocar & 0 & 0 & 3 & 0 & 0 & 0 & 0 & 3 & 0 & ) & 0 & 0 & 0 & 3 & 3 & 0 & 0 & $\begin{array}{ll}0 & 3 \\
\end{array}$ & 0 & 0 & 0 & 3 & 0 & 0 & 0 & 0 & \begin{tabular}{l|l}
0 & 3 \\
\end{tabular} & 0 & 0 & 3 & 0 & 0 & 0 & $\begin{array}{l}0 \\
0\end{array}$ & $\begin{array}{l}0 \\
0\end{array}$ & $\begin{array}{ll}3 & 0\end{array}$ & 0 & 0 & 0 & $1 \mathrm{c}$ & 0 & 0 & 0 \\
\hline Modiolula & & 3 & 0 & 0 & 0 & 0 & 0 & 3 & 0 & & 00 & 0 & 0 & 1 & 3 & 0 & 0 & 03 & 0 & 0 & 0 & 0 & 0 & 0 & 0 & 3 & 30 & 0 & 0 & 3 & 0 & 0 & 0 & 00 & $\begin{array}{l}0 \\
0\end{array}$ & $\begin{array}{ll}30 \\
0\end{array}$ & 0 & 0 & 0 & 1 & 0 & & \\
\hline Rapana & 0 & 0 & 3 & 10 & 0 & 0 & $0 \mid$ & 0 & 3 & ) & 00 & 0 & 2 & 1 & 2 & 2 & $0 \mid 3$ & $\begin{array}{l}3 \\
3\end{array}$ & 0 & 0 & 0 & 3 & 0 & $0 \mid$ & 2 & $3(5$ & \begin{tabular}{l|l}
0 & 0 \\
\end{tabular} & 0 & 3 & 1 & 1 & 0 & 0 & $\begin{array}{l}0 \\
0\end{array}$ & 0 & $\begin{array}{ll}0 & 3\end{array}$ & 3 & 0 & 0 & 0 & 3 & 3 & 0 \\
\hline & & 3 & 0 & 0 & 0 & 0 & 0 & 3 & 0 & & 0 & 30 & 0 & 0 & 0 & 0 & 3 & 0 & 0 & 3 & 0 & 0 & 3 & 1 & 0 & 0 & $\begin{array}{ll}3 & 3\end{array}$ & 0 & 0 & 0 & 3 & 0 & 0 & & 0 & $\begin{array}{ll}0 & 1\end{array}$ & 2 & 0 & 0 & 1 & 0 & & \\
\hline pido & & & 0 & & & & $0 \mid$ & & & & & & & 0 & & 0 & & & & & 0 & $|0|$ & & & $0 \mid 3$ & 3 & \begin{tabular}{l|l}
3 & 0
\end{tabular} & & 0 & $0 \mid$ & 3 & & & & & & 3 & & & & 0 & 0 & \\
\hline
\end{tabular}

